TID-4500 (37th Ed.) CATEGORY UC-37

INSTRUMENTATION

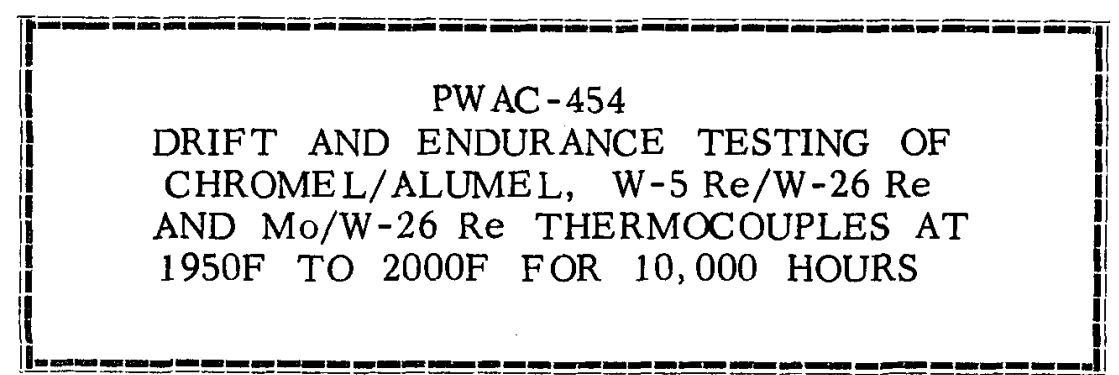

AEC RESE ARCH AND DEVE LOPMENT REPORT

CONTR ACT

AT $(30-1)-2789$

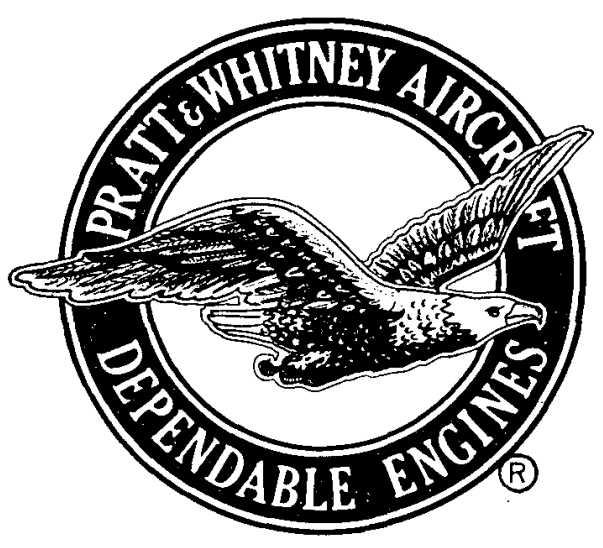

Issued

February 23, 1965

Printed in U.S.A. Price $\$ 2.00$. Available from the Office of Technical Services, Department of Commerce, Washington 25, D.C.

\title{
$\begin{array}{llllllllllllllllllllll}P & R & A & T & T & E & W & H & I & T & N & E & Y & A & \text { I } & R & C & R & A & F & T\end{array}$
} DIVISION OF UNITED AIRCRAFT CORPORATION C ANEL
MI D D L E TOWN
CON NECT I C UT 
Page No.

Table of Figures

I. Introduction $\ldots \ldots \ldots$

II. Summary $\ldots \ldots \ldots$

III. Description of Test Thermocouples 10

IV. Description of Test Assemblies 11

V. Test Procedure

VI. Post-Test Calibration and Test Results

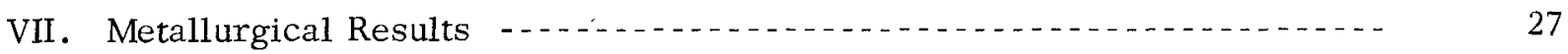

VIII. Conclusions 
PWAC - 454

$\theta$

$\ominus$ 


\section{TABLE OF FIGURES}

Figure No.

Title

Page No.

Summary of Data for 1/8-Inch OD Cb-1 Zr Clad Thermocouples ......

2 Thermocouple Test Retort Design $\ldots \ldots$

$3 \quad 1 / 8$ In. OD Cb-1 Zr Clad W-5 Re/W-26 Re Thermocouples

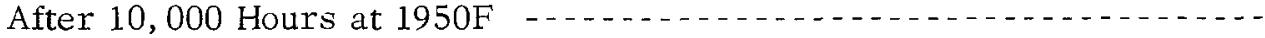

$4 \quad 1 / 8 \mathrm{In}$. OD $\mathrm{Cb}-1 \mathrm{Zr}$ Clad Mo/W-26 Re Thermocouples After

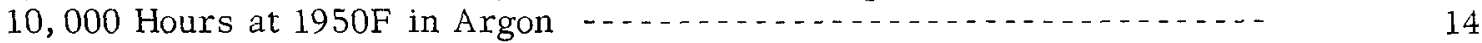

5 1/8-Inch OD, Cb-1 Zr-Clad, W-5 Re/W-26 Re Thermocouples .......

$6 \quad 1 / 8$ In. OD $\mathrm{Cb}-1 \mathrm{Zr}$ Clad C/A Thermocouples After

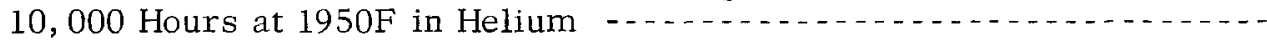

$7 \quad 1 / 8 \mathrm{In}$. OD $\mathrm{Cb}-1 \mathrm{Zr}$ Clad C/A Thermocouples After

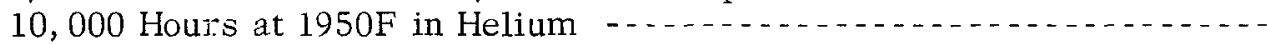

8 Performance Curve for Ten $\mathrm{C} / \mathrm{A}, \mathrm{Cb}-1 \mathrm{Zr}$ Clad, Alumina Insulated $1 / 8 \mathrm{In}$. OD Thermocouples at $1950-2000 \mathrm{~F}$ in

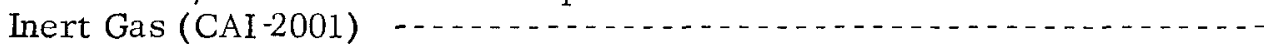

9 Performance Curve for Ten C/A, Cb-1 $\mathrm{Zr}$ Clad, Alumina Insulated, 1/8" OD Thermocouples at 1950-2000F in

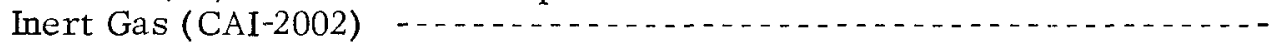

10 Performance Curve for Eight W-5 Re/W-26 Re, Cb-1 Zr Clad, Alumina Insulated 1/8" OD Thermocouples at 1950-2000F

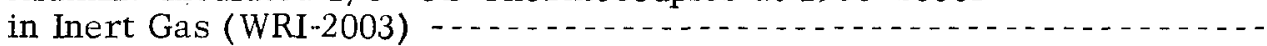

11 Performance Curve for Eight W-5 Re/W-26 Re, Cb-1 Zr Clad, Alumina Insulated 1/8" OD Thermocouples at 1950-2000F

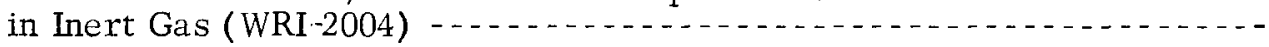

12 Performance Curve for Seven Mo/W-26 Re, Cb-1 Zr Clad, Alumina Insulated $1 / 8^{\prime \prime}$ OD Thermocouples at $1950-2000 \mathrm{~F}$ in Inert Gas (MWI-2005)

13 Effect of Mo/Pt and W-26 Re/Pt Deviations on the

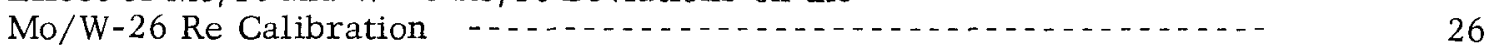

14 Cb-1 Zr Clad Wall ID Region of T/C from Test CAI-2002

15 Cb-1 Zr Clad Wall Cross-Section from T/C Test CAI-2002

16 Chromel (Right) and Alumel (Left) Post-Test T/C Wires, Test CAI-2002 $\ldots \ldots \ldots$

17 Platinum/Platinum-13 Rhodium Contamination from Test CAI 2002

18 Electron Microprobe Analysis of $\mathrm{Pt} / \mathrm{Pt}-13 \mathrm{Rh}$ Contamination 
Figure No.

Title

19

20

21

22
Cb-1 Zr T/C Clad Wall Cross-Section from T/C Test WRI-2004 -..... -

Cb-1 Zr Clad Wall ID Region of T/C from Test WRI-2004 ......... .

Cb-1 Zr Clad Wall ID Region of T/C from Test WRI-2003 _.........

Contamination of $\mathrm{Pt} / \mathrm{Pt}-13 \mathrm{Rh}$ by Manganese
Page No.

33

34

35

36 
PWAC - 454

DRIFT AND ENDURANCE TESTING OF CHROMEL/ALUMEL, W-5 Re/W-26 Re, AND Mo/W-26 Re THERMOCOUPLES AT $1950 \mathrm{~F}$ TO $2000 \mathrm{~F}$ FOR 10,000 HOURS

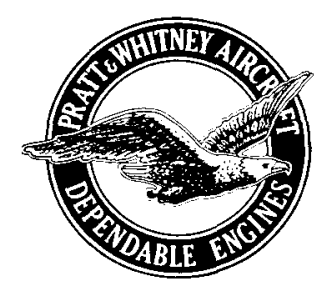

Prepared By: Salvatore Fanciullo

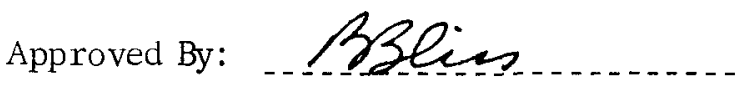

P. Bliss 


\section{INTRODUCTION}

The testing described in this report is part of a continuing program of thermocouple development. The phase of testing reported deals with an operating temperature range of $1950 \mathrm{~F}$ to $2000 \mathrm{~F}$, and was done to provide drift and endurance data for long periods of time on Chromel/Alumel, W-5 Re/W-26 Re, and Mo/W-26 Re thermocouples.

As stated above, this program is continuing and other tests are in progress which are not reported in this document.

Current work includes the testing of Mo/Cb, W-3 Re/W-25 Re, W-5 Re/W-26 Re, and C/A thermocouples at temperatures to $2300 \mathrm{~F}$ in inert gas and liquid metal environments. Experiments in the near future will elevate the operating temperature limit of most of these to $2500 \mathrm{~F}$ and will include other combinations of interest. 


\section{SUMMARY}

Tests of 1/8-inch OD Cb-1 Zr clad, alumina-insulated Chromel/Alumel, W-5 Re/W-26 Re, and Mo/W-26 Re thermocouples were conducted to determine 10,000-hour stability in inert gas at 1950F to $2000 \mathrm{~F}$. The results indicate that all of the above thermocouples drifted less than one and one-half percent for the 10,000-hour period. The $\mathrm{C} / \mathrm{A}$ and $\mathrm{W}-5 \mathrm{Re} / \mathrm{W}-26 \mathrm{Re}$ tests remained within a one and one-half percent accuracy limit for the duration of the test. The Mo/W-26 Re thermocouples showed a larger inaccuracy limit due to a poor match of the thermoelements. Fig. 1 summarizes the data for the 10,000-hour period. No test thermocouple failures occurred. 
P W A C - 454

FIG 1

SUMMARY OF DATA FOR 1/8-INCH OD Cb-1Zr CLAD THERMOCOUPLES TEST TEMPERATURE: $2000 \mathrm{~F}$

TEST DURATION: $\quad 10,000$ HOURS

Test

Code No.

C AI - 200 I

$(\mathrm{X}-285 \mathrm{~A})$

C AI- 2002

$(\mathrm{X}-285 \mathrm{~B})$

WRI-2003

(X-531A)

WRI -2004

$(\mathrm{X}-531 \mathrm{~B})$

MWI-2005

$(\mathrm{X}-286)$
TC Type

C/A

$\mathrm{C} / \mathrm{A}$

W-5 Re/W-26 Re

W-5 Re/W-26 Re

Mo/W-26 Re

\begin{tabular}{|c|c|c|c|}
\hline \multirow[b]{2}{*}{ Max. Drift, \% } & \multicolumn{2}{|c|}{ Accuracy } & \multirow[b]{2}{*}{ Quan. Tested } \\
\hline & High, \% & Low, \% & \\
\hline-1.45 & +0.75 & -1.15 & 10 \\
\hline-0.55 & +0.75 & -0.5 & 10 \\
\hline-0.25 & +0.10 & -1.3 & 8 \\
\hline-0.55 & 0 & -1.2 & 8 \\
\hline-0.90 & +3.2 & -1.9 & 7 \\
\hline & & & 43 \\
\hline
\end{tabular}




\section{DESCRIPTION OF TEST THERMOCOUPLES}

All the thermocouples tested were 1/8-inch OD, $\mathrm{Cb}-1 \mathrm{Zr}$ clad, and alumina-insulated. The clad wall thickness is nominally 0.022 inch and No. 24 gage wire is used for the thermoelements. The alumina is an electrofused product and is used as preformed shapes. All thermocouples are made by swaging.

The Chromel, Alumel, W-5 Re, and W-26 Re thermoelements were procured from the Hoskins Manufacturing Company, Detroit, Michigan. The molybdenum is type MO-73 wire procured from the Sylvania Electric Products of Towanda, Pennsylvania. The columbium wire was fabricated by Fansteel of North Chicago, Illinois, from an ingot produced by Wah Chang of Albany, Oregon. The columbium was processed to CANEL Specification CS-1800.

The thermocouples were assembled after all detail metal parts had been cleaned and the ceramic prefired to drive out excess moisture. All parts were handled with white nylon gloves to minimize possible contamination. The unswaged assemblies were then baked in a vacuum at $400 \mathrm{~F}$ for 4 to 8 hours, backfilled with clean, dry argon, and cooled to room temperature. The assemblies were removed from the bake out retorts immediately before swaging, at which time the ends were crimped closed over small rubber stoppers. After swaging the clad OD was cleaned and then the ends were removed for electrical inspection and weld preparation. The units were then rebaked in a vacuum at $400 \mathrm{~F}$ for another 4 to 8 hours and backfilled again with clean, dry argon. The hot junctions of the thermocouples were formed by tungsten inert gas welding in an inert gas-filled weld box in which gas conditions were maintained at less than $2.5 \mathrm{ppm}$ oxygen and $10 \mathrm{ppm}$ moisture. The thermocouples were loaded into the weld chamber from the bake out retort just before closing the weld chamber. Both ends of the swaged assembly were welded to eliminate moisture absorption after removal from the weld chamber. Each thermocouple was then X-rayed to verify the quality of the hot junction. All the thermocouples tested except the Chromel/Alumel units incorporated a fused grounded hot junction. The C/A units were fabricated with ungrounded hot junctions to eliminate a possible formation of a low melting eutectic with the $\mathrm{Cb}-1 \mathrm{Zr}$ clad at the test temperature. The junctions of these C/A thermocouples were formed before assembling the wires and alumina into the sheath. Two of the C/A junctions inadvertently became grounded during fabrication and were tested to determine significant differences and if the formation of a $\mathrm{Cb}-1 \mathrm{Zr}$-nickel eutectic was a problem.

The procedure described is not the current fabrication procedure used at Pratt \& Whitney AircraftCANEL, but is the basis for the improved procedure currently in use. A more up-to-date procedure may be found in Appendix I-A of PWAC-422*.

\footnotetext{
*'Thermocouple Development - Lithium-Cooled Reactor Experiment", S. Fanciullo, Pratt \& Whitney
} Aircraft-CANEL Division, PWAC-422. 


\section{DESCRIPTION OF TEST ASSEMBLIES}

The retort design used for the W-5 Re/W-26 Re and the Mo/W-26 Re tests consisted of a 4-inch schedule 40, Type 310 stainless steel pipe approximately 18 inches long (Fig. 2). The inside walls of the retort were lined with two to three layers of 0.005 -inch thick tantalum foil to act as a "getter" for contaminants. Each thermocouple was also spiral-wrapped with tantalum foil and was introduced into the retort through swage type mechanical fittings. The hot junctions of the test thermocouples terminated in a Cb-1 Zr isothermal block. Two alumina-insulated unsheathed $\mathrm{Pt} / \mathrm{Pt}-13 \mathrm{Rh}$ reference grade thermocouples were also terminated in the $\mathrm{Cb}-1 \mathrm{Zr}$ isothermal block. The $\mathrm{Pt} / \mathrm{Pt}-13 \mathrm{Rh}$ wire diameters were 0.025 inch. Gas inlet and evacuation lines were located in the cover with the thermocouples. Figs. 3 and 4 show the assemblies after test completion. Eight W-5 Re/W-26 Re thermocouples were tested in each retort. Seven Mo/W-26 Re thermocouples were tested. The cold ends of the thermocouples were terminated in separate hermetic chambers. Thermocouple extension wire was brought out of the chamber through hermetic electrical seals. This chamber and the test retort were leak-checked using a helium mass spectrometer. No leaks were detected with a machine sensitivity of $10^{-9} \mathrm{scc} / \mathrm{sec}$.

An improved retort was designed for the two Chromel/Alumel tests. An alumina protection tube with a 1-1/2 inch OD was sealed to a Type 316 stainless steel head assembly with " $O$ " -rings. The "O"-rings operated at temperatures less than $200 \mathrm{~F}$. The thermocouples were inserted into the retort through swage type mechanical fittings. Two alumina-insulated unsheathed Pt/Pt-13 $\mathrm{Rh}$ reference thermocouples were used. Inlet gas and vacuum lines were located in the stainless cover and body. Fig. 5 is a typical assembly. These assemblies were also mass spectrometer leak-tight. Ten test thermocouples were in each assembly. Hermetic chambers sealing the thermocouple cold ends were also used. 
P W AC - 454

FIG 2

THERMOCOUPLE TEST RETORT DESIGN

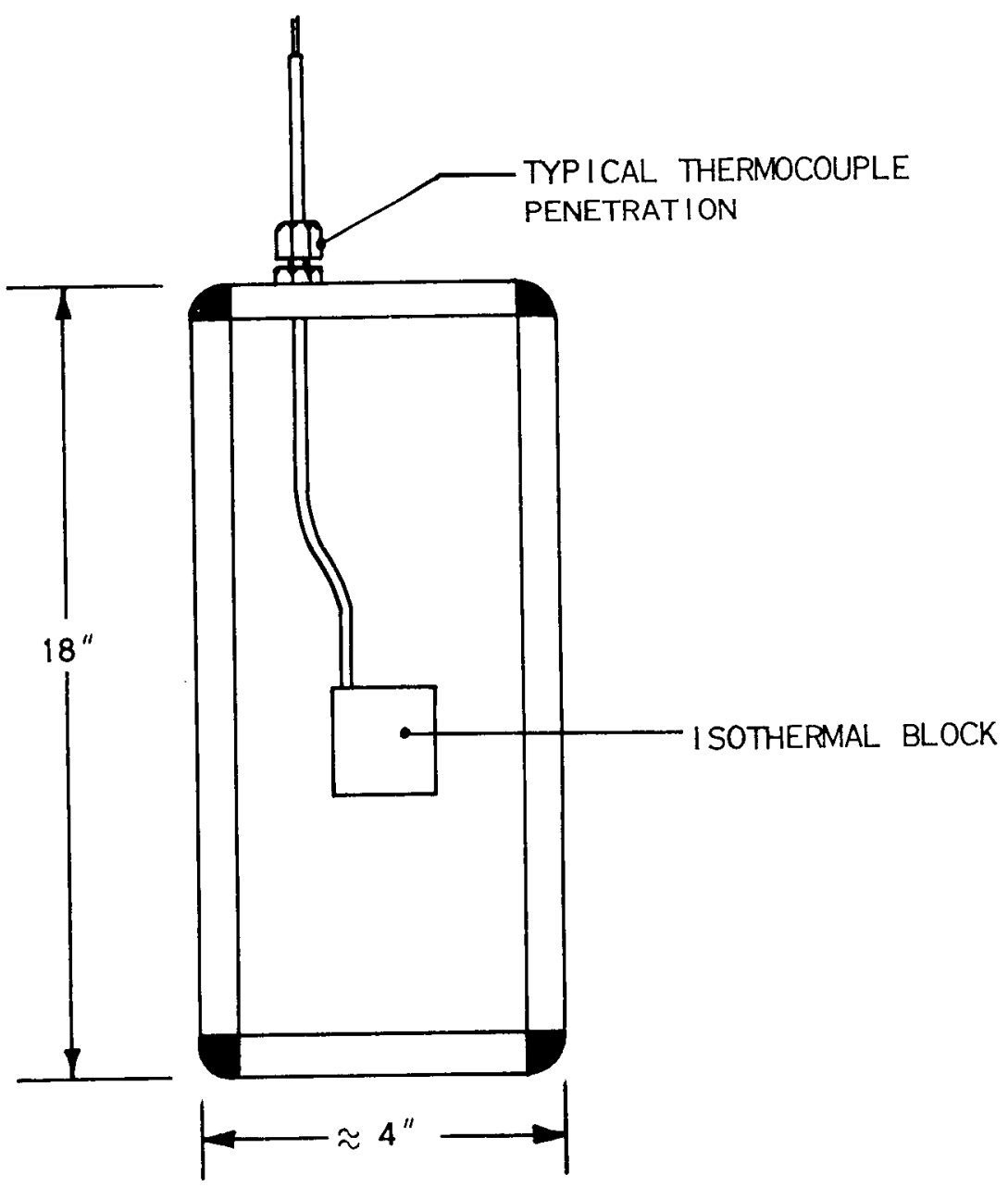




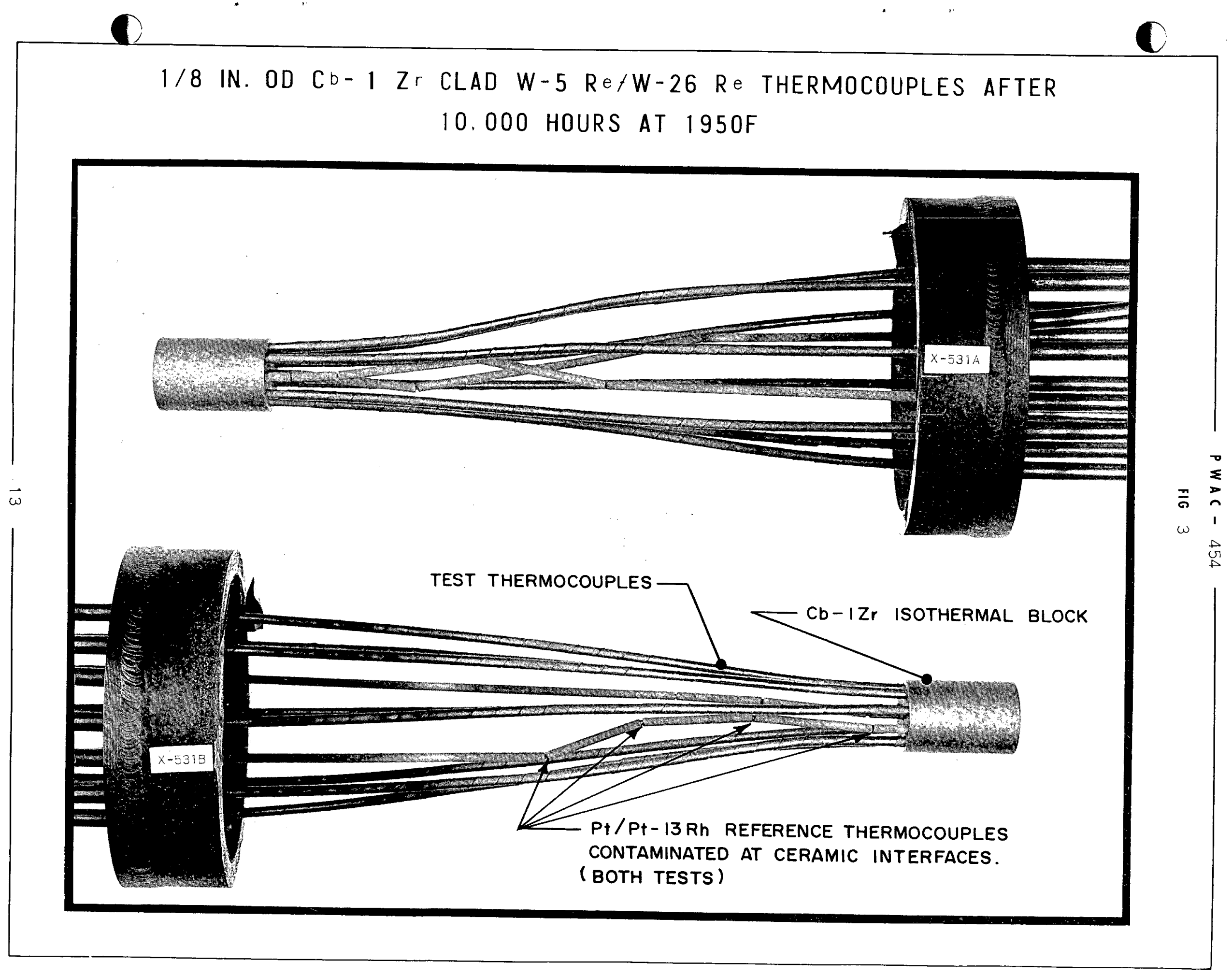


P WAC - 454

FIG 4

$1 / 8$ IN. OD Cb-1 Zr CLAD MO/W-26 Re THERMOCOUPLES AFTER 10,000 HOURS AT $1950 \mathrm{~F}$ IN ARGON

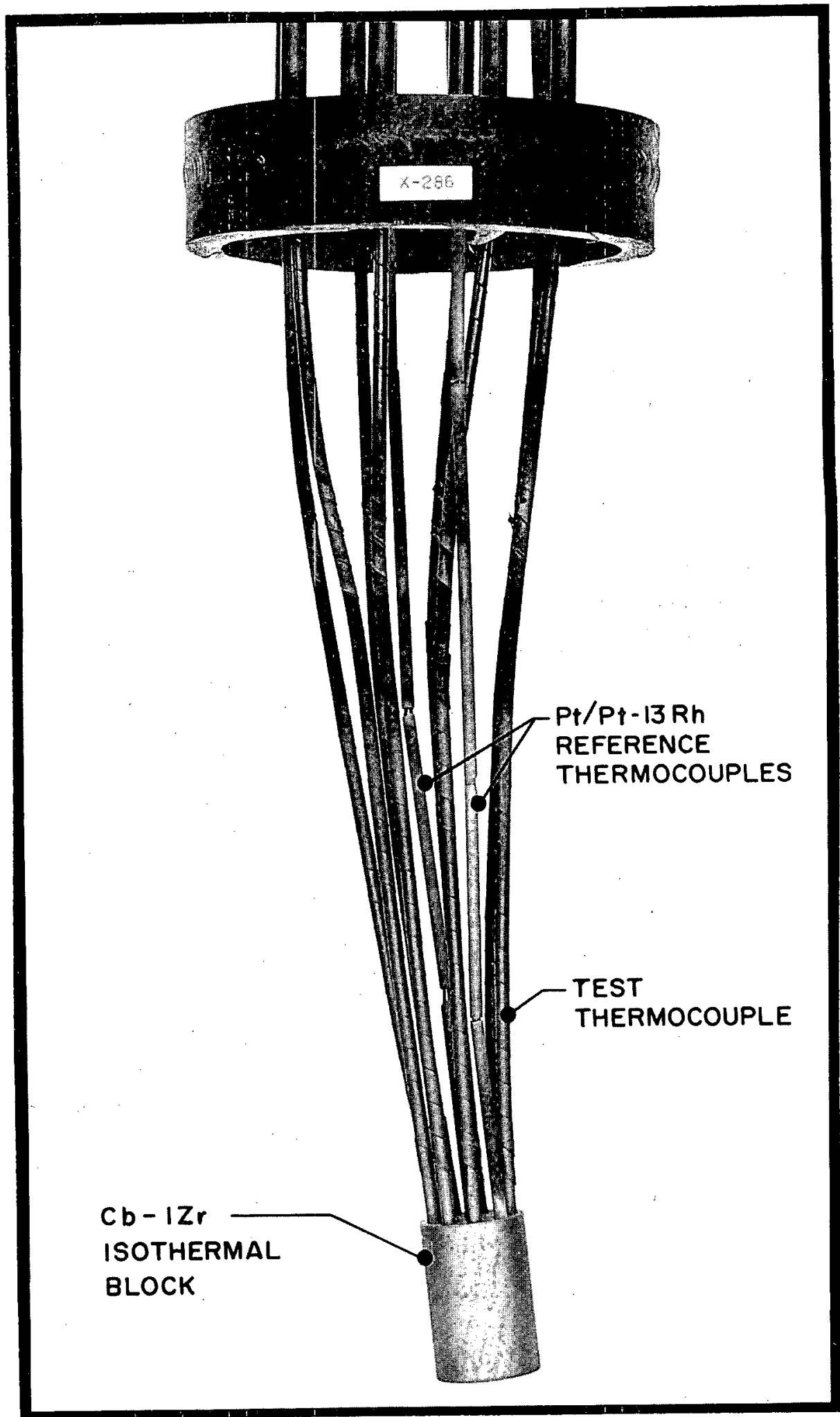




\section{1/8-INCH OD, Cb-1 Zr-CLAD, W-5 Re/W-26 Re THERMOCOUPLES} AFTER 500 HOURS AT 1950F IN ARGON

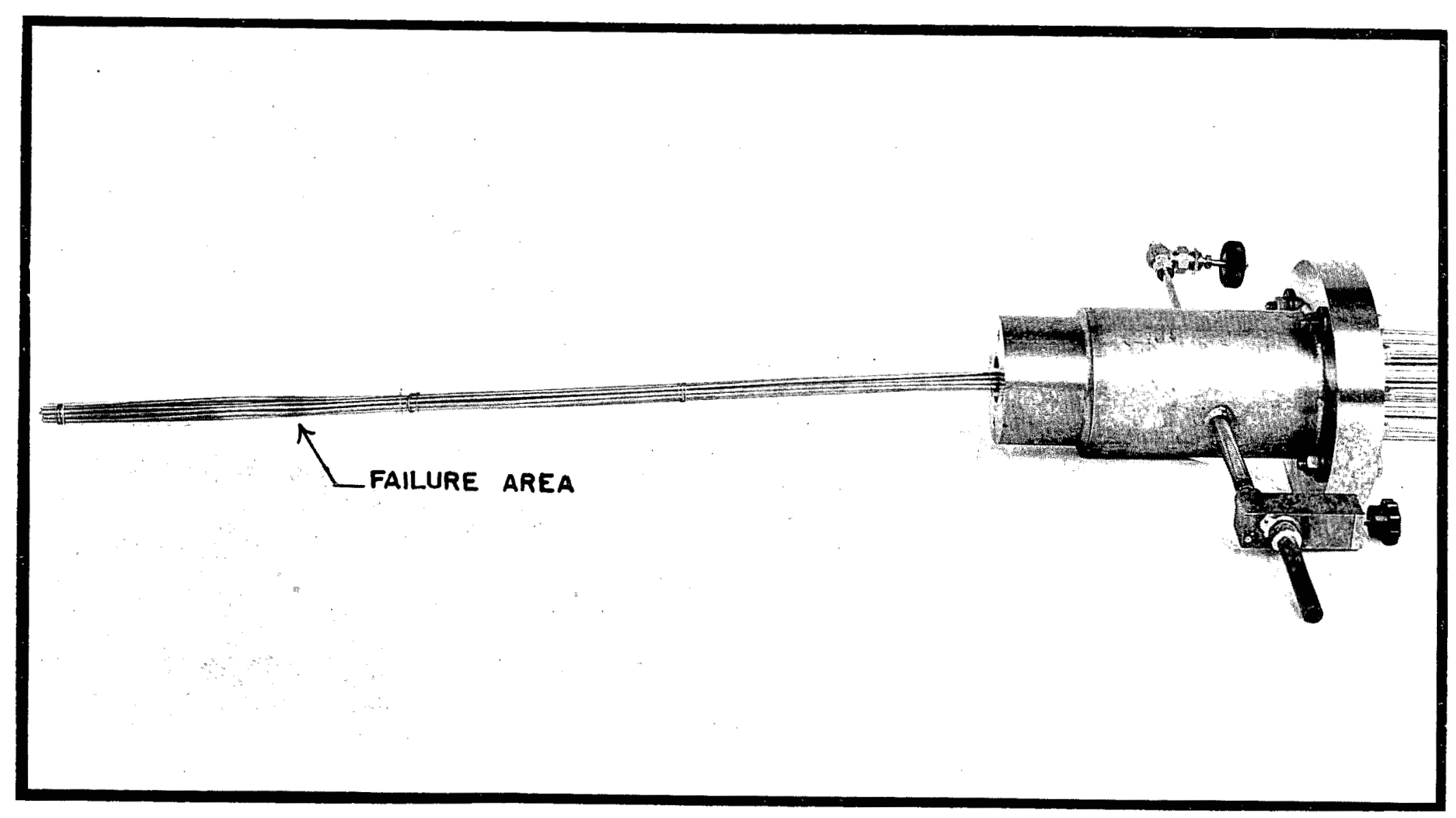




\section{TEST PROCEDURE}

The test assemblies were evacuated and backfilled with purified inert gas several times prior to heat-up. Gas was then purged through the retort and seal chamber until a purity of less than 2.5 ppm oxygen and $10 \mathrm{ppm}$ moisture was measured from the effluent gas. The hermetic seal chamber was then evacuated, and the vacuum maintained until the test was brought up to $1950 \mathrm{~F}$ to $2000 \mathrm{~F}$. The retort was purged continually during initial heat-up and the quality of the effluent gas was continually monitored. A minimum purity of less than $2.5 \mathrm{ppm}$ oxygen and $10 \mathrm{ppm}$ moisture was maintained by limiting the rate of temperature rise. At $600 \mathrm{~F}$, with acceptable gas quality, the gas analysis instrumentation was removed and the gas flow was shut off, trapping inert gas at 3 to 5 psig inside the retort. The temperature was then elevated at the rate of $100 \mathrm{~F} / \mathrm{hr}$ until the desired operating temperature was reached. Data was recorded every hour initially and then every four hours after the first few days of operation. Once each week, or at not more than 200-hour intervals, the instrumentation was calibrated and a set of data was taken on a Honeywell Rubicon potentiometer. This data was then analyzed and plotted. 


\section{POST-TEST CALIBRATION AND TEST RESULTS}

The general indicated trend of the thermocouples on test was to drift positively. The one exception was the second C/A test which indicated a slight negative shift. All thermocouples had been within the $\pm 1 \%$ accuracy limit at the start of the test.

Original plots of the data indicate this positive shift and at the time, there was no obvious reason to disbelieve the data.

The only problem encountered during the 10,000 hours of test was the failure of several tests of heaters used in the first C/A test and the Mo/W-26 Re test. No thermocouples were lost in any of the tests.

When each test had completed 10,000 hours, it was carefully opened for examination. The general condition of the test thermocouples was excellent, showing only minor exterior contamination. In the two C/A tests, Figs. 6 and 7, it was obvious that the Pt/Pt-13 $\mathrm{Rh}$ reference thermocouples had deteriorated. A metallic deposit was evident on the ceramic insulators, and the platinum wires looked as though they had melted in places. On the W-5 Re/W-26 Re and Mo/W-26 Re thermocouple tests, Figs. 3 and 4, the hot junctions of the platinum standards looked rather clean but there appeared to be many areas of attack along the length of the thermocouples wire at the interfaces of the alumina pieces.

We decided to remove the worst looking platinum standard from each test and replace it with a new unit for a post-test calibration of the assembly. It was fully expected that thermal gradient effects would have been established during the 10,000 hours of testing but, of course, the magnitude could not be predicted. Great care was taken to reposition the assembly in the test thermal gradient exactly as it had been tested, and after the recalibration run the thermocouple assemblies were moved both into and out of the heat zone, adjusting power to keep the hot junctions at the test temperature, to determine the magnitude of the gradient effects .

Complete data was obtained for all of the tests except the Mo/W-26 Re test. Both of the original standards were damaged in handling prior to the recalibration; therefore, no comparison of standards could be made. No thermal gradient data was obtained from this test.

The results of the $\mathrm{C} / \mathrm{A}$ test recalibrations indicated that a good comparison could not be made between the original standard, the new standard and the test thermocouples. Two separate recalibrations of each assembly failed to give reliable information about the original standard; however, we believe the comparison of the new standard and the test thermocouples was valid. This comparison showed, at least, that the original platinum standard readings were erroneous. This, of course, can be attributed to the gross contamination and apparent shifting of the hot junction or the formation of many parallel hot junctions. Figs. 8 and 9 show the cirift characteristics of each C/A test, based on the post-test recalibration. The drift is represented as a band showing the spread in thermocouple readings for the duration of the test. These curves were adjusted from the original data based on the post-test calibration and the initial test data. Both tests maintained an accuracy of $\pm 1.5 \%$ of reading; however, one $\mathrm{C} / \mathrm{A}$ test did exhibit a greater drift.

The effect of shifting the thermal gradient only served to verify that its effect can be eliminated if more of the affected thermocouple area is placed in the hot zone. It also verified the difficulty in calibrating a thermocouple that is no longer homogeneous.

No differences in performance were noted in the two thermocouples which were inadvertently grounded.

The data taken from the post-test calibration on the two W-5 Re/W-26 Re correlated very well with the actual test data. As in the $\mathrm{C} / \mathrm{A}$ tests, the calibration indicated that the $\mathrm{Pt} / \mathrm{Pt}-13 \mathrm{Rh}$ reference thermocouples had actually been drifting negatively. In this case, however, the contamination did not influence the $\mathrm{Pt} / \mathrm{Pt}-13 \mathrm{Rh}$ reference in the same fashion as in the $\mathrm{C} / \mathrm{A}$ tests. This will be discussed later. The information presented in Figs. 10 and 11 also show a data band signifying the 
spread in data for this period. The accuracy for any thermocouple for the duration of the test was within $\pm 1.5 \%$ of reading. The maximum drift was slightly greater than $0.5 \%$. There was very good agreement between the two tests as witnessed by the fact that the drift curve for the second test can be superimposed on the curve of the first. Shifting of the thermal gradient yielded the same results as in the C/A tests.

The Mo/W-26 Re thermocouples always gave a high output relative to the predicted calibration curve, as shown in Fig. 12. The initial spread of the seven thermocouples, however, was only $7 \mathrm{~F}(+57$ to $+64 \mathrm{~F})$. The spread at the end of the test based on the post-test calibration was only $8 \mathrm{~F}(+38$ to $+46 \mathrm{~F})$. Several separate tests were conducted to determine the source of this high positive output:

1. Evaluation of the test stands

2. Recalculation of the original molybdenum and W-26 Re calibration data.

3. Clad swaged versus bare wire molybdenum thermocouple tests

4. Recalibration of various molybdenum wire samples

5. Calibration of other swaged molybdenum/W-26 Re thermocouples

All the above tests concluded that the observed thermocouple error was due to a slight mismatch of one thermoelement to the other. Fig. 13 illustrates the effect of deviations in the Mo/Pt and $\mathrm{W}-26 \mathrm{Re} / \mathrm{Pt}$ calibration on the Mo/W-26 Re calibration. Small deviations in the Mo/Pt calibration are greatly magnified because its EMF/temperature slope is very steep as compared to Mo/W-26 Re. 


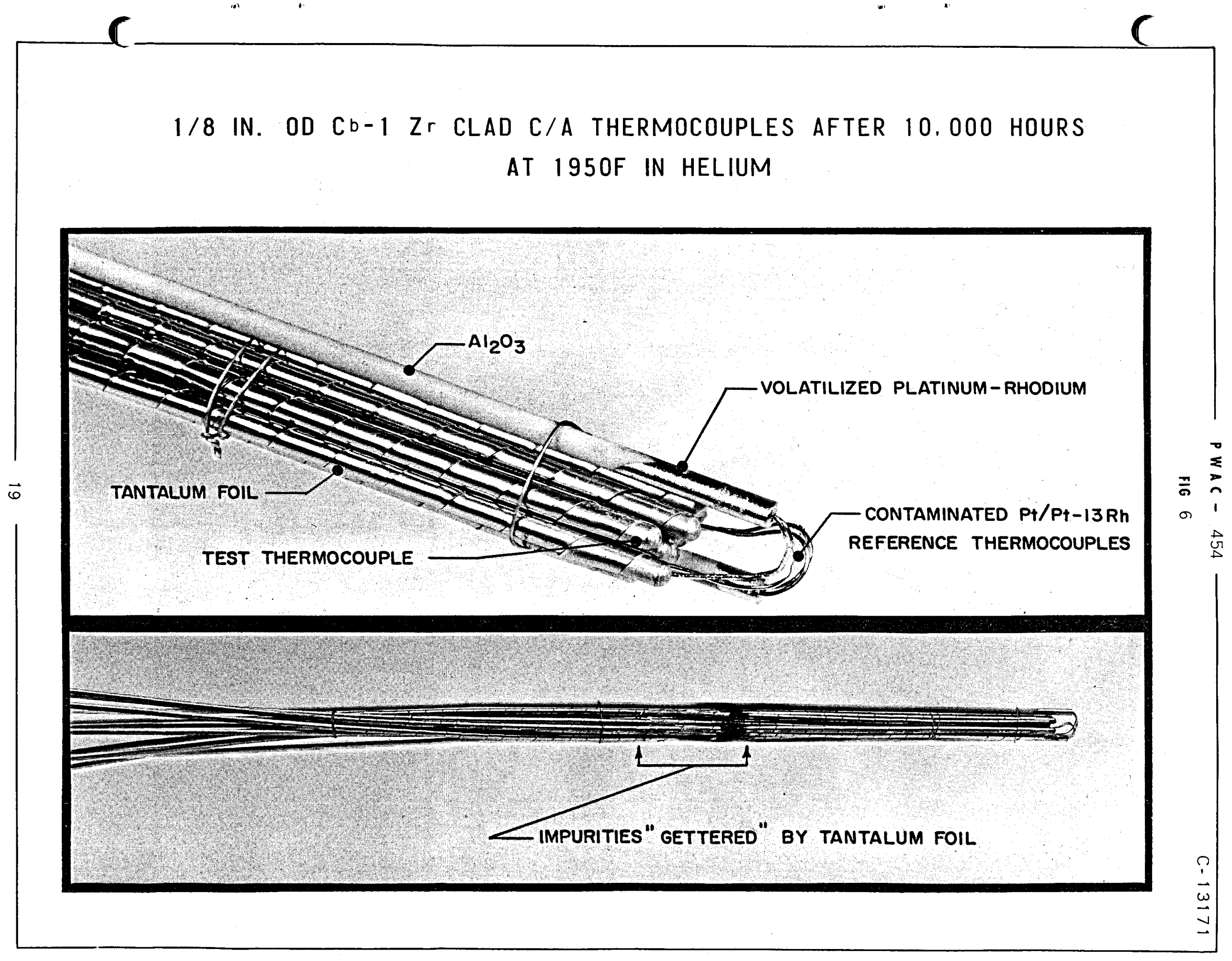


$1 / 8$ IN. OD Cb-1 Zr CLAD C/A THERMOCOUPLES AFTER 10,000 HOURS AT $1950 \mathrm{~F}$ IN HELIUM

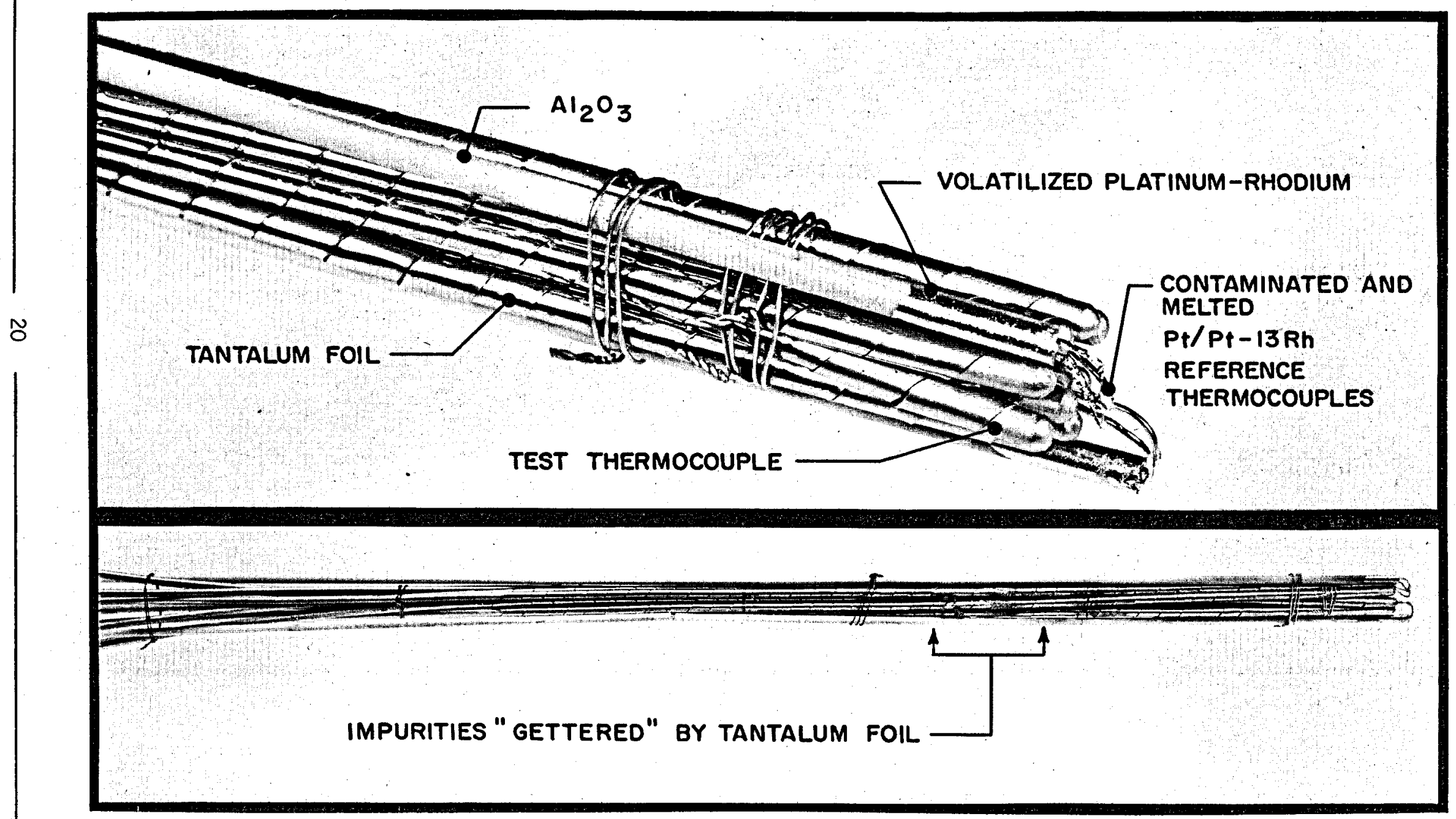




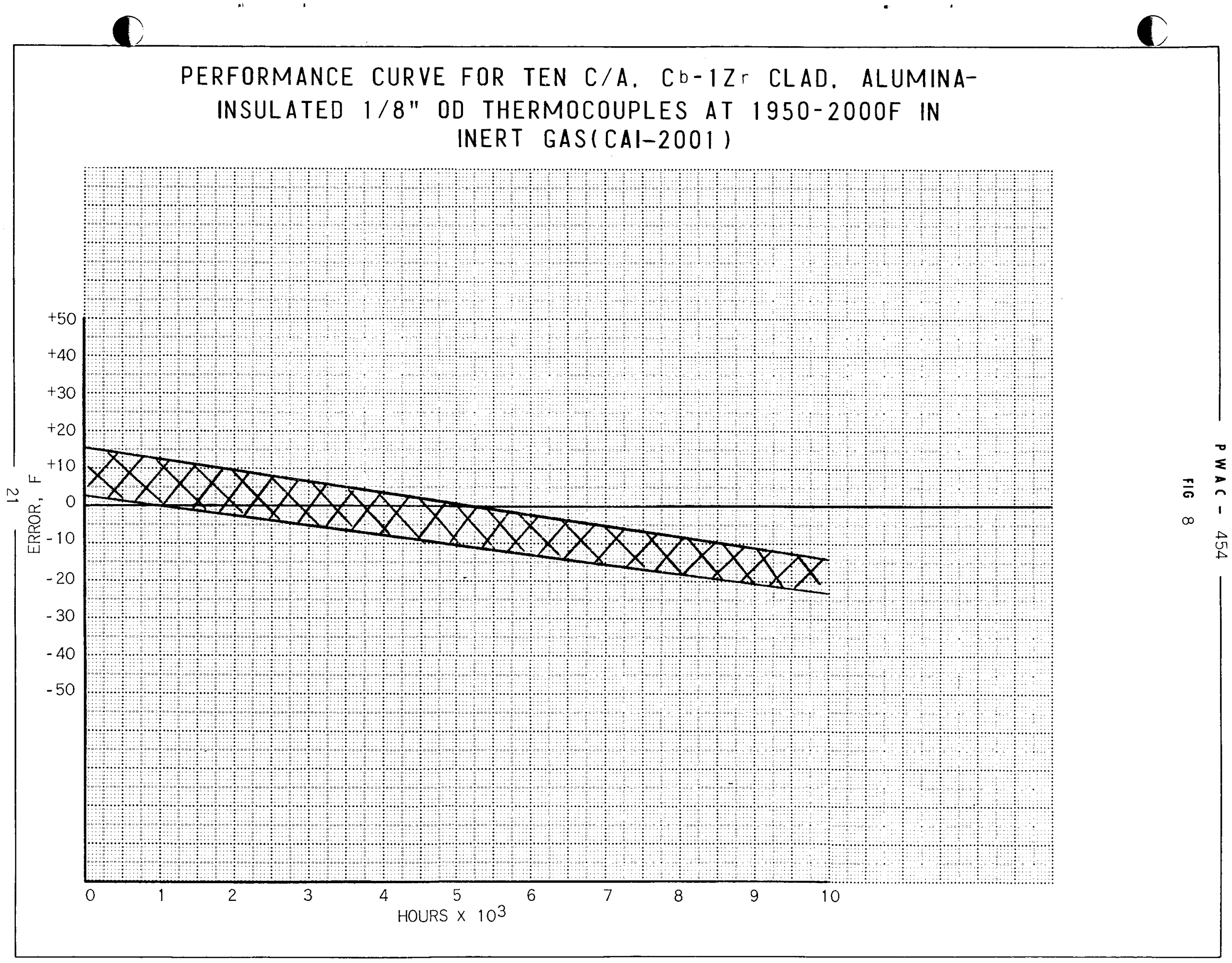




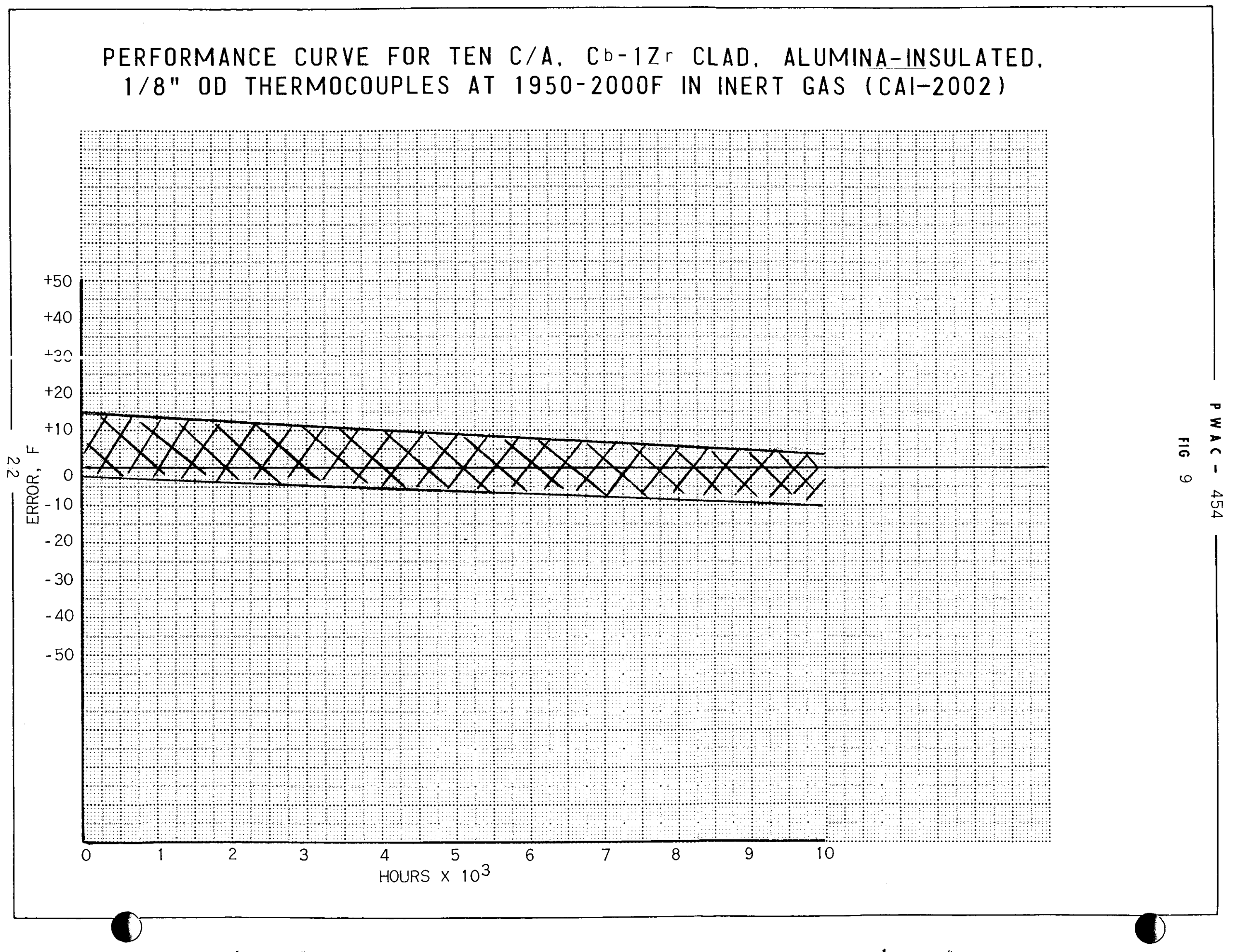




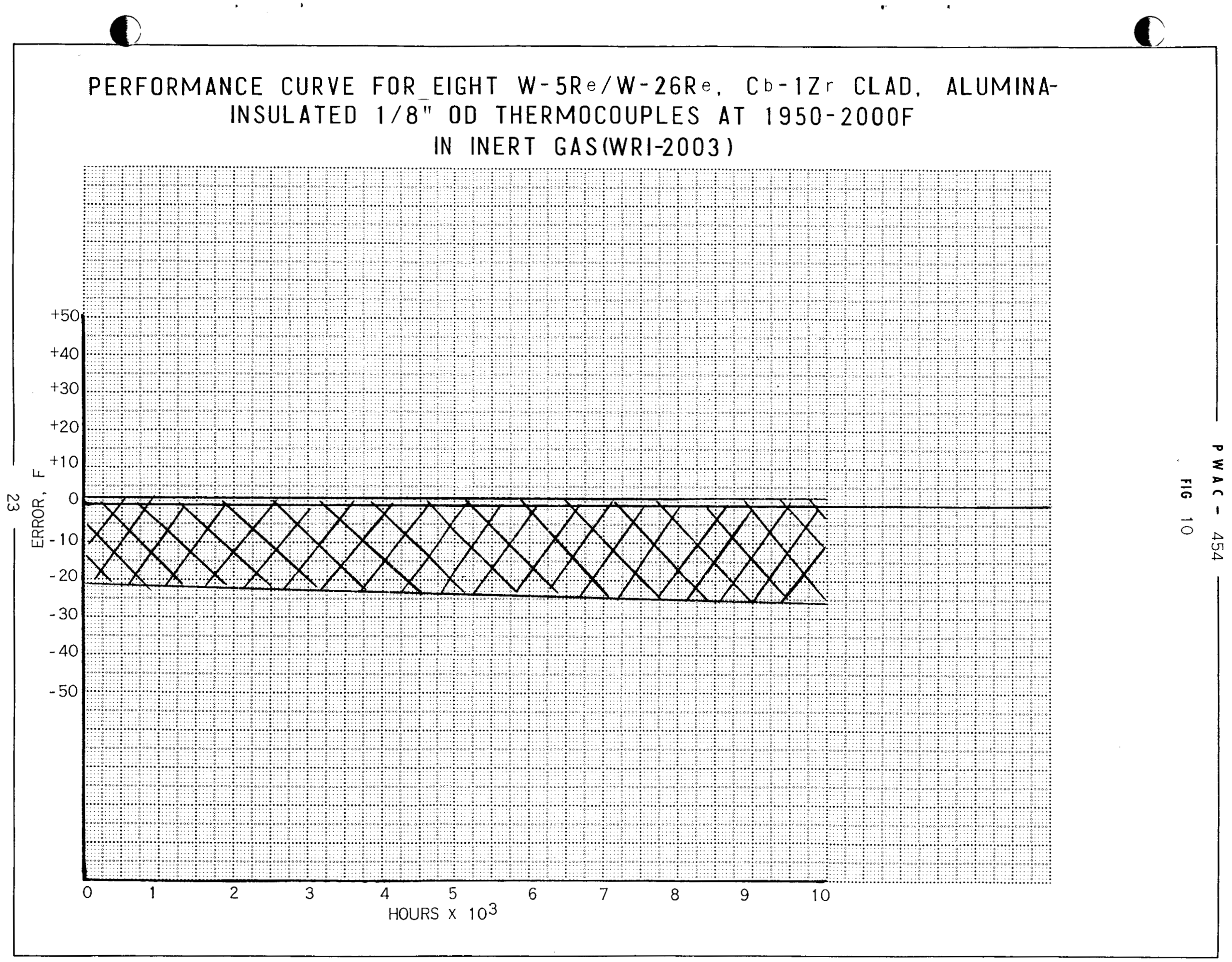




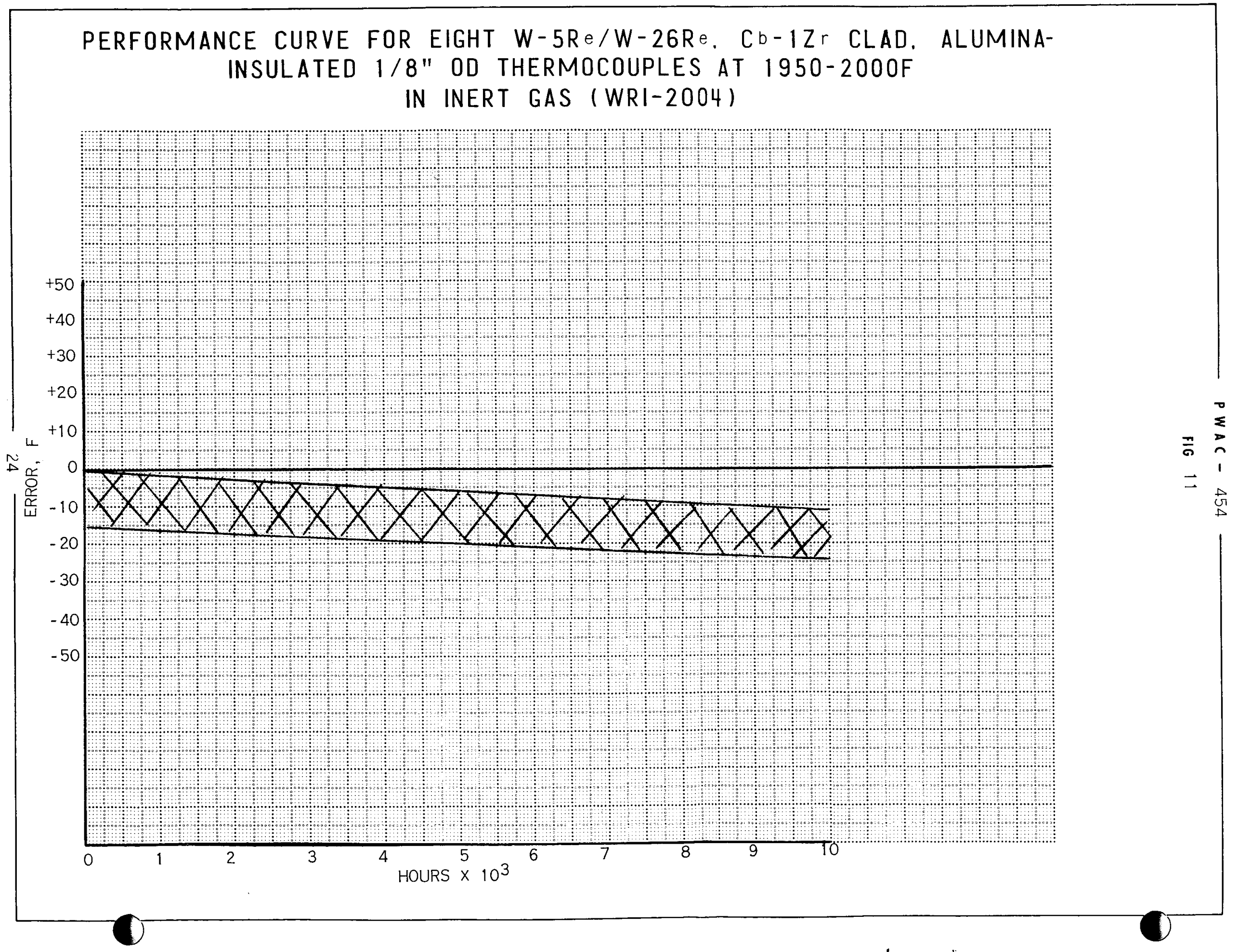


PERFORMANCE CURVE FOR SEVEN Mo/W-26Re, Cb-1Zr CLAD, ALUMINAINSULATED 1/8" OD THERMOCOUPLES AT 1950-2000F

IN INERT GAS (MWI-2005)

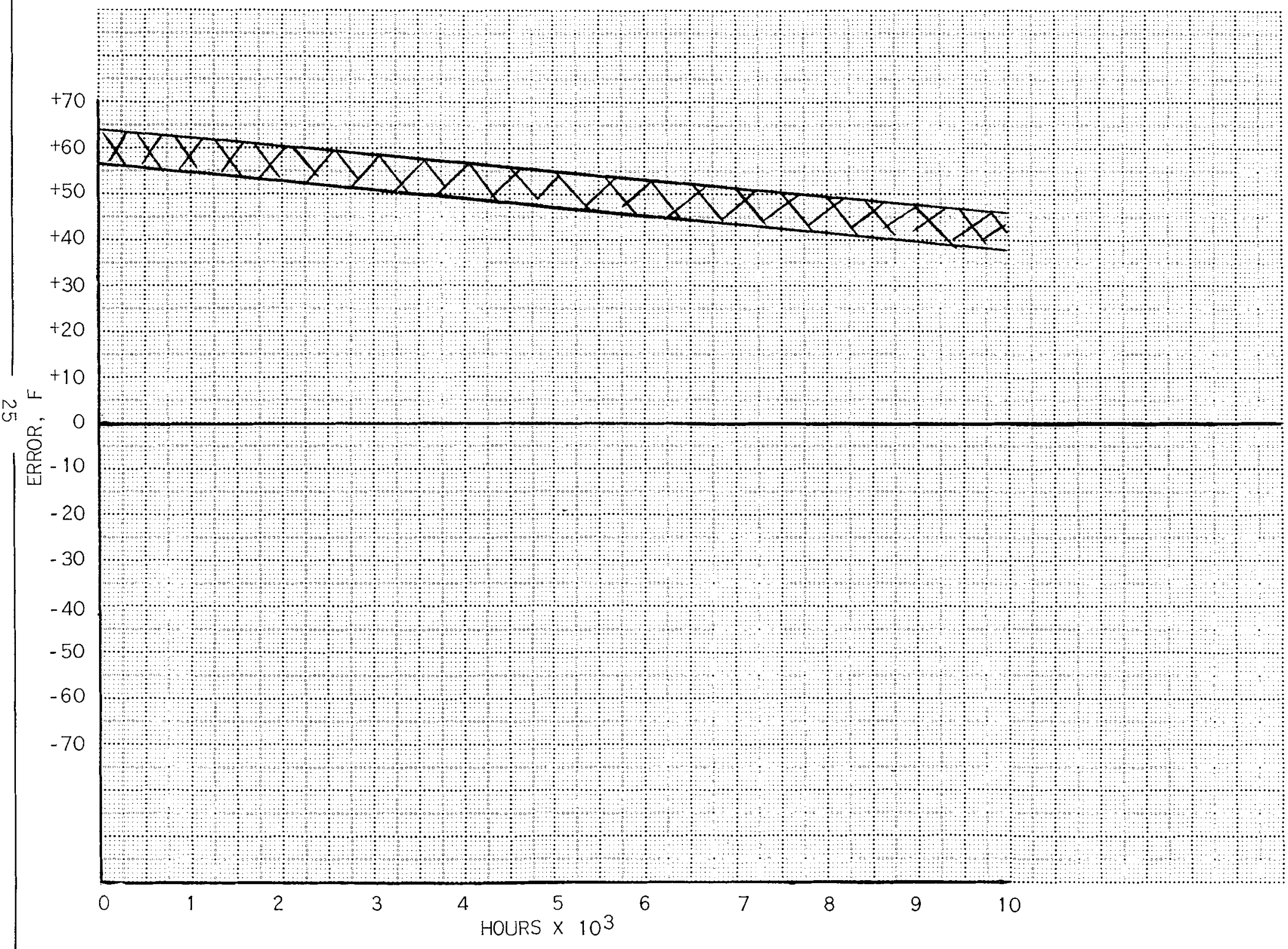


PWAC - 454

FIG 13

\section{EFFECT OF MO/Pt AND W-26 Re/Pt DEVIATIONS ON THE MO/W-26 Re CALIBRATION}



\section{METALLURGICAL RESULTS}

Chromel/Alumel Tests

Examination of the $\mathrm{Cb}-1 \mathrm{Zr}$ clad of the $\mathrm{C} / \mathrm{A}$ thermocouples showed the clad wall to be moderately contaminated with nitrogen in the form of $\mathrm{Cb}_{2} \mathrm{~N}$ (Figs. 14 and 15). The nitrogen was most probably present in dilute concentration in the inert gas environment. $\mathrm{Cb}_{2} \mathrm{Al}, \mathrm{Cb}_{3} \mathrm{Al}$, and small amounts of $\mathrm{Cb}_{5} \mathrm{Si}_{3}$ were detected on the ID of the clad wall at the $\mathrm{Cb}-1 \mathrm{Zr} / \mathrm{Al}_{2} \mathrm{O}_{3}$ interface where the test temperature was sufficient to promote interdiffusion. A more complicated diffusion product was formed at the thermocouple hot junctions (Fig. 14). It is believed that in this area the temperature was sufficient to promote dissolutioning of the C/A wires (see Fig. 16). The long test duration allowed the constituents of $\mathrm{C} / \mathrm{A}$ to diffuse to the ID of the clad wall where they entered into the diffusion reaction. Apart from the limited amount of dissolutioning observed, the $\mathrm{C} / \mathrm{A}$ thermoelements appeared to be in excellent condition. The grain growth observed in the Alumel appeared to be excessive; however, no adverse effects were noted. No contamination of the C/A thermoelements was detected. The amount of oxide contamination observed in the $\mathrm{Cb}-1 \mathrm{Zr}$ clad wall is the normal amount to be expected at these operating temperatures, since oxygen is released from the alumina upon reduction of the ceramic by the zirconium present in the $\mathrm{Cb}-1 \mathrm{Zr}$ sheath .

No eutectic formation was noted in the two $\mathrm{C} / \mathrm{A}$ thermocouples which were grounded to the $\mathrm{Cb}-1 \mathrm{Zr}$ sheath.

The examination of the Pt/Pt-13 $\mathrm{Rh}$ reference thermocouple showed that melting had occurred in the exposed hot junction (see Fig. 17). Metallographic examination revealed a two-phase structure which was identified as a (Pt-Rh)-Si eutectic. A literature survey* disclosed that at $2000 \mathrm{~F}$ silicon was the only logical contaminant which could induce melting of the $\mathrm{Pt} / \mathrm{Pt}-13 \mathrm{Rh}$ by diffusing into the wires. Electron microprobe analysis verified this as shown by the X-ray image in Fig. 18. Quantitative analysis of the silicon-rich phase was found to be slightly less than $5 \%$. This correlates well with the literature which gives 5.44 as the percent of the silicon-rich phase in the eutectic structure in the $\mathrm{Pt}-\mathrm{Si}$ system. The addition of rhodium to the $\mathrm{Pt}$-Si binary must change the eutectic composition, although to what degree is not known.

It is believed that the silicon which caused this reaction came from the alumina retort used to house the test thermocouples. The silicon initially tied up in the alumina retort must have been released by some unknown reducing agent which may also have been present in the alumina retort.

W-5 Re/W-26 Re and Mo/W-26 Re Tests

Metallographic examination of the $\mathrm{Cb}-1 \mathrm{Zr}$ clad showed severe nitrogen contamination in the form of $\mathrm{Cb}_{2} \mathrm{~N}$ (see Figs. 19, 20, and 21). It is believed that nitrogen diffused through the Type 310 stainless steel retort used in these tests. Where the temperature was high enough, the formation of $\mathrm{Cb}_{2} \mathrm{Al}$, $\mathrm{Cb}_{3} \mathrm{Al}$, and small amounts of $\mathrm{Cb}_{5} \mathrm{Si}$ are noted at the clad/ceramic interface (see Figs 20 and 21 ).

The W-5 Re, W-26 Re, and Mo thermoelements were in good condition and no contamination was observed.

Contamination of the $\mathrm{Pt} / \mathrm{Pt}-13 \mathrm{Rh}$ reference thermocouples was also evident in these tests although the type of reaction appeared to be different than that of the $\mathrm{C} / \mathrm{A}$ tests. Micro-examination revealed a diffusion process was operative particularly at the interface of each piece of alumina insulation. The hot junctions of these $\mathrm{Pt} / \mathrm{Pt}-13 \mathrm{Rh}$ thermocouples were inserted into an $\mathrm{Cb}-1 \mathrm{Zr}$ isothermal block which apparently afforded some protection. Microprobe studies indicated the penetration of manganese into the $\mathrm{Pt}$ and $\mathrm{Pt}-13 \mathrm{Rh}$ thermoelements. This resulted from a mass transfer of the manganese from the Type 310 stainless steel retort (see Fig. 22).

*"Constitution of Binary Alloys", M. Hansen, 1958, p. 1140 . 


\section{Cb-1Zr CLAD WALL ID REGION OF T/C FROM TEST CAI-2002}

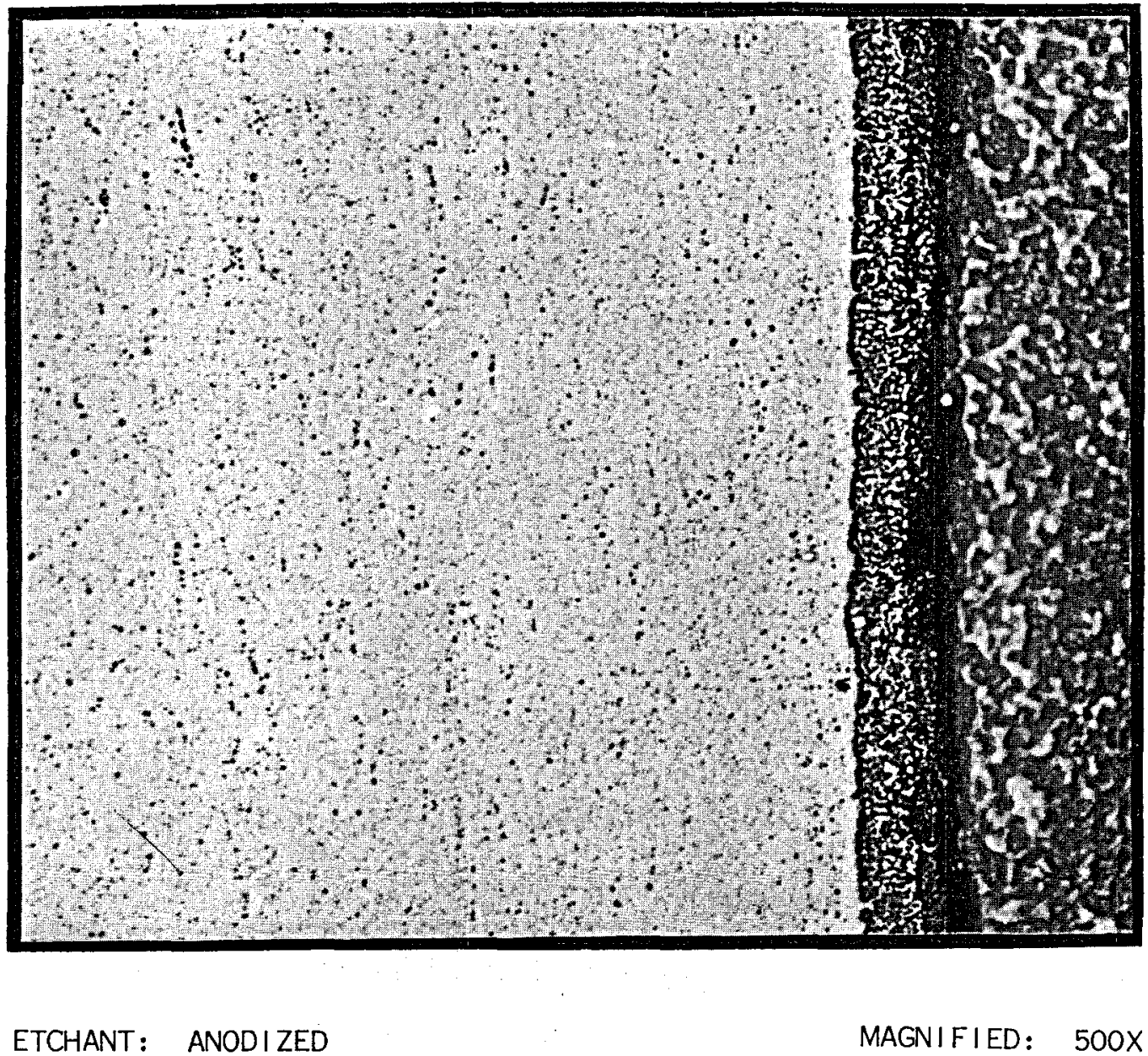

APPARENTLY ELEMENTS FROM THE C/A T/C WIRES HAVE COMBINED WITH THE AI FROM THE DISSOCIATED ALUMINA TO FORM THIS COMPLEX DIFFUSION ZONE. $\mathrm{Cb}_{2} \mathrm{~N}$ AND $\mathrm{ZrO}_{2}$ ARE EVIDENT IN THE CLAD WALL. 
PWAC - 454

FIG 15

\section{Cb-1Zr CLAD WALL CROSS-SECTION FROM T/C TEST CAI-2002}

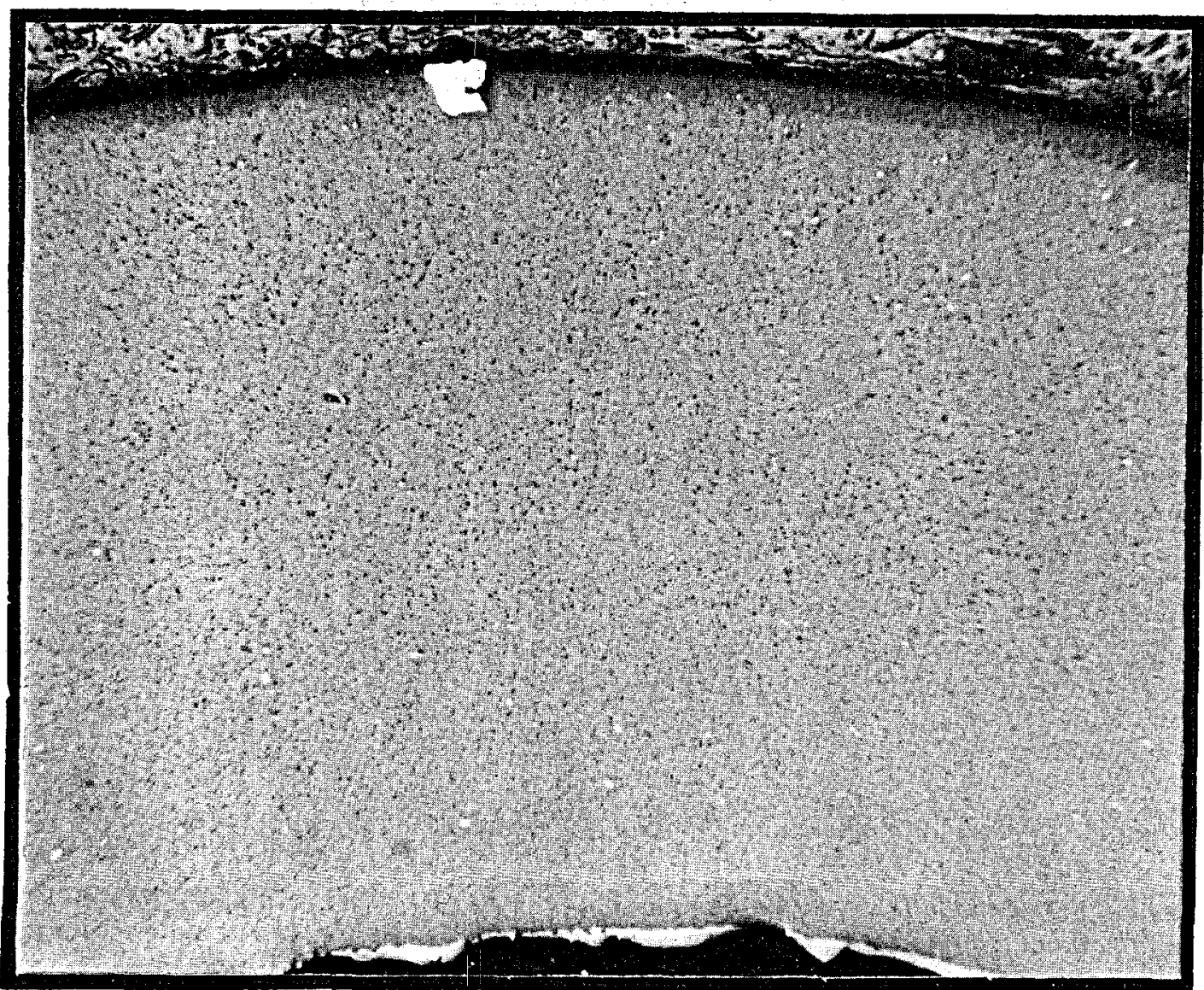

ETCHANT: ANODIZED

MAGNIFIED: $\quad 200 X$

LARGE PARTICLE AT OD SURFACE AND SMALLER LIGHT PARTICLES IN CLAD WALL ARE $\mathrm{Cb}_{2} \mathrm{~N}$. MINUTE DARK PHASE IS $\mathrm{ZrO}_{2}$. A LAYER OF $\mathrm{Cb}_{3} \mathrm{Al}$ CAN BE OBSERVED AT THE ID SURFACE. 
PWAC - 454

CHROMEL (RIGHT) AND ALUMEL (LEFT) POST-TEST T/C WIRES. TEST CAI-2002

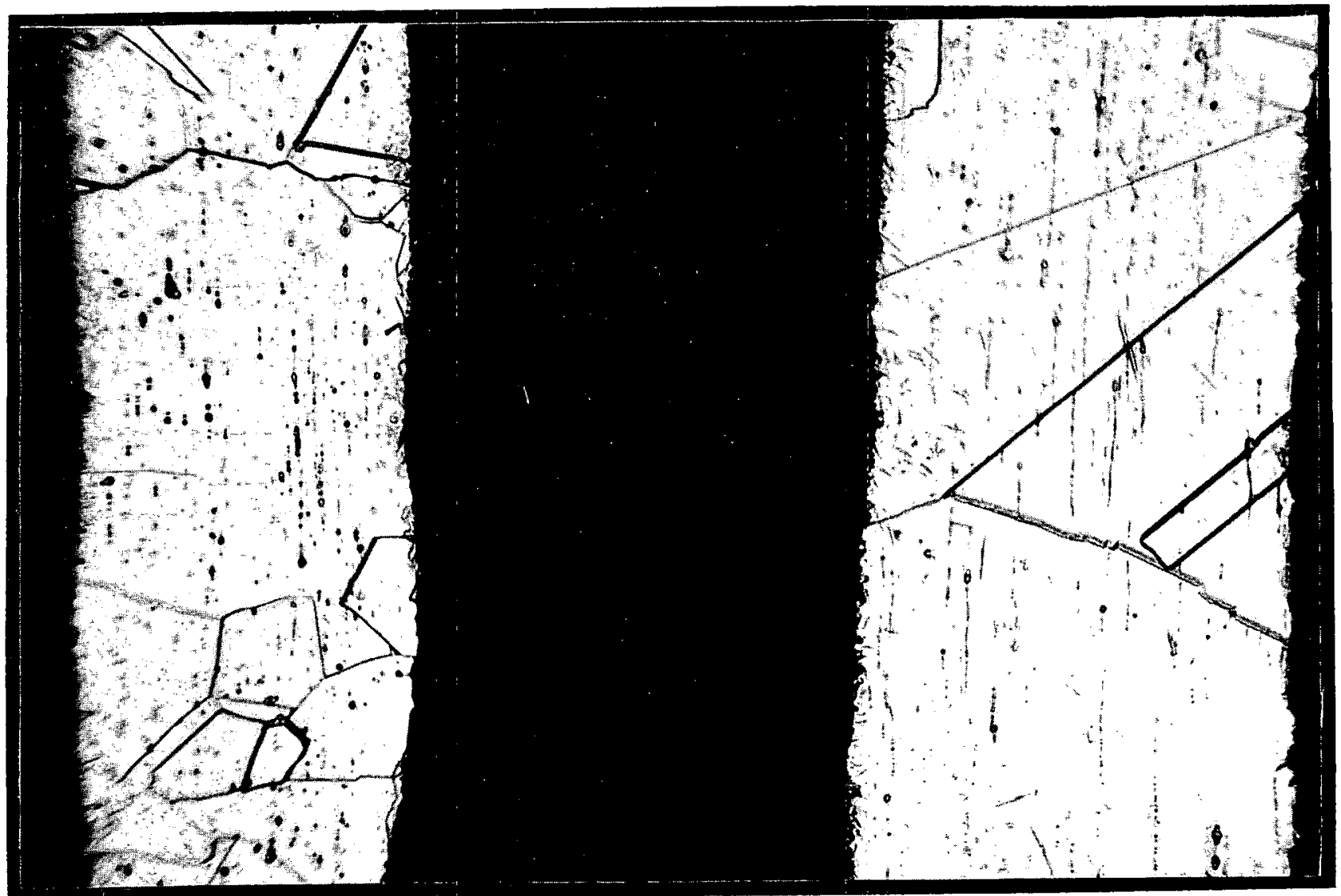

ETCHANT: $\quad 60 \mathrm{HCL}, 20 \mathrm{HNO}_{3}, \mathrm{CUCl}_{3} \mathrm{SAT}$.

MAGNIFIED: $\quad 100 X$

WIRES SHOW NO CONTAMINATION BUT SOME EVIDENCE OF DISSOLUTIONING WAS NOTED IN THE HOT ZONE. 
P WAC - 454

PLATINUM/PLATINUM-13 RHODIUM CONTAMINATION FROM

\section{TEST CAI-2002}

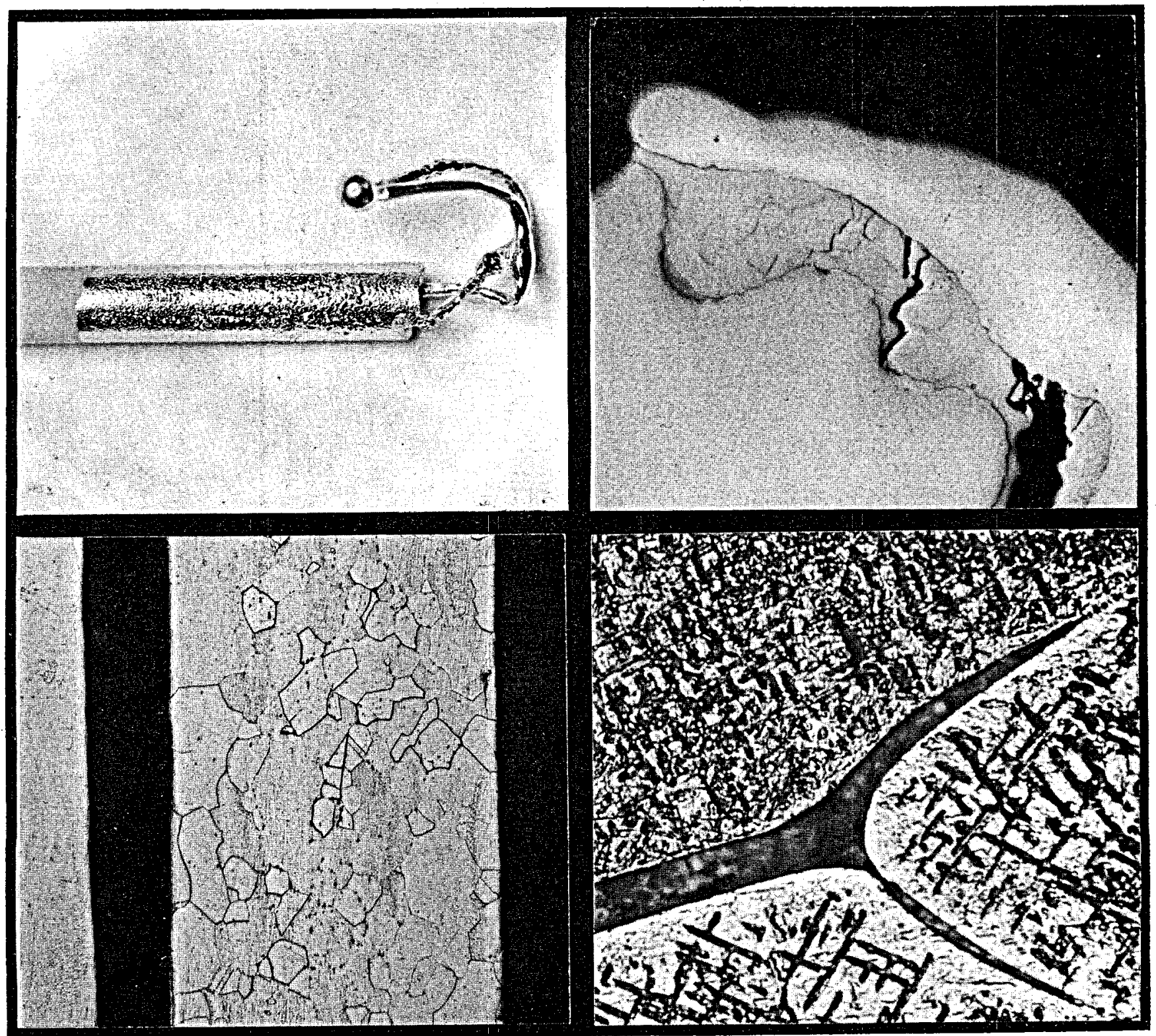

1. MACROSHOT OF POST-TEST Pt/Pt-13Rh T/C FROM TEST CAI-2002 SHOWING MELTING CAUSED FROM THE FORMATION OF THE Pt-Si EUTECTIC.

2. 500X, AS-POLISHED, Pt-Si EUTECTIC STRUCTURE IN MELTED T/C SECTION.

3. 200S, AQUA REGIA ETCH POSSIBLE INTERNAL OXIDATION OF Pt-13Rh T/C WIRE IN UN-MELTED SECTION.

4. 500X, AQUA REGIA ETCH, MELTED PORTION OF T/C BEAD. ETCHED-OUT PHASE IS SILICON-RICH EUTECTIC PHASE. 
P W A - 454

HIG 18

\section{ELECTRON MICROPROBE ANALYSIS OF $\mathrm{Pt} / \mathrm{Pt}-13 \mathrm{Rh}$ CONTAMINATION}

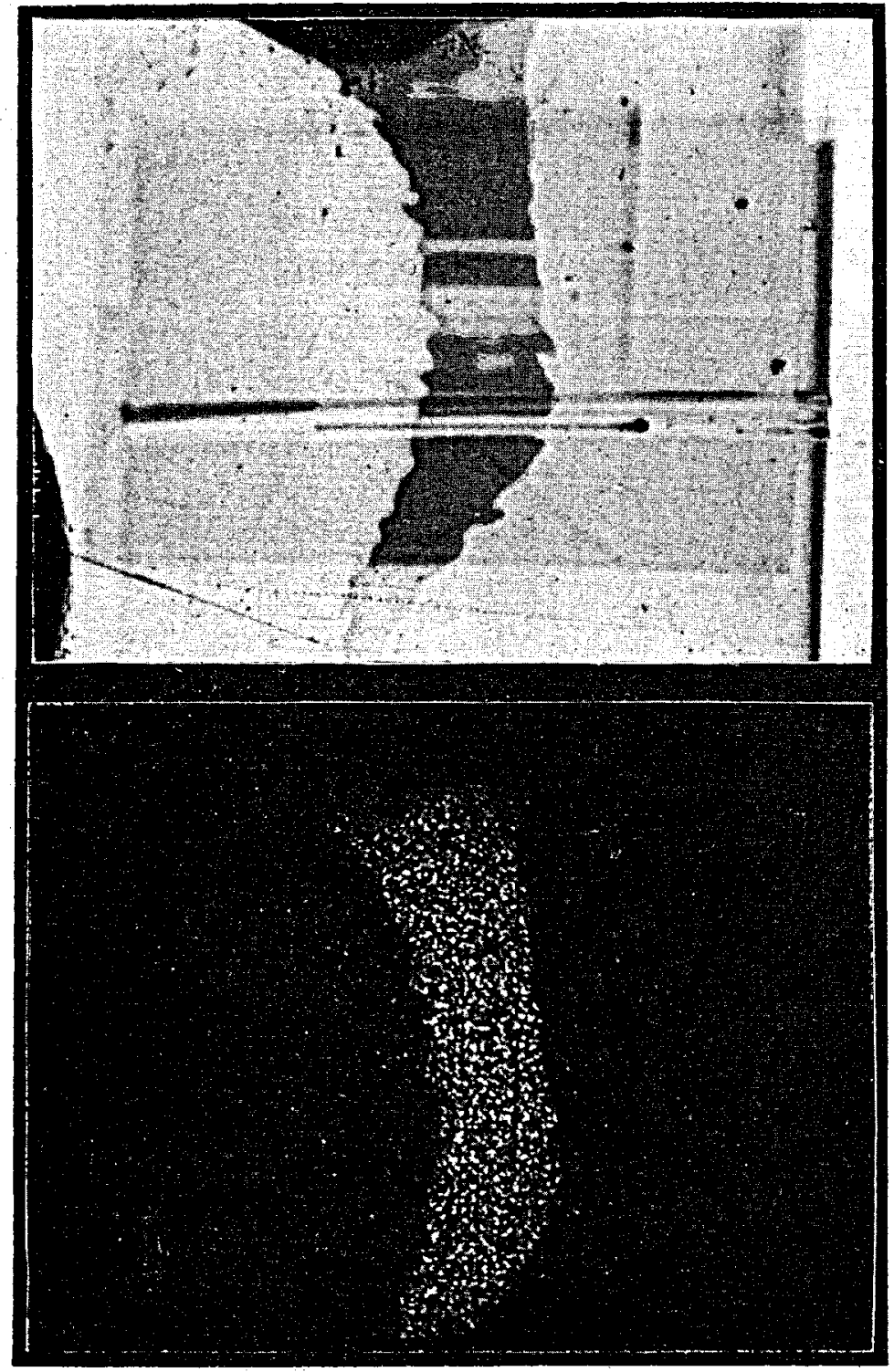

ETCHANT: NONE

MAGNIFIED: $\quad 450 X$

TOP: PHOTOMICROGRAPH OF PL T/C LEG CONTAMINATED WITH SILICON IN TEST CAI- 2002. DARK "PENINSULA" AREA IS SILICON-RICH PORTION OF Pt-Si EUTECTIC STRUCTURE (5.44 W/O Si). GRAY TRACES AND AREAS RESULTED FROM CARBON DEPOSITION DURING PROBE EXAMINATION.

BOTTOM: SILICON X-RAY IMAGE OF AREA SHOWN IN TOP FIGURE. ELECTRON MICROPROBE RESULTS INDICATED APPROXIMATELY 5 W/O SI IN THE SILICON-RICH EUTECTIC STRUCTURE. 
PWAC - 454

FIG 19

Cb-1Zr T/C CLAD WALL CROSS-SECTION FROM T/C TEST WRI-2004

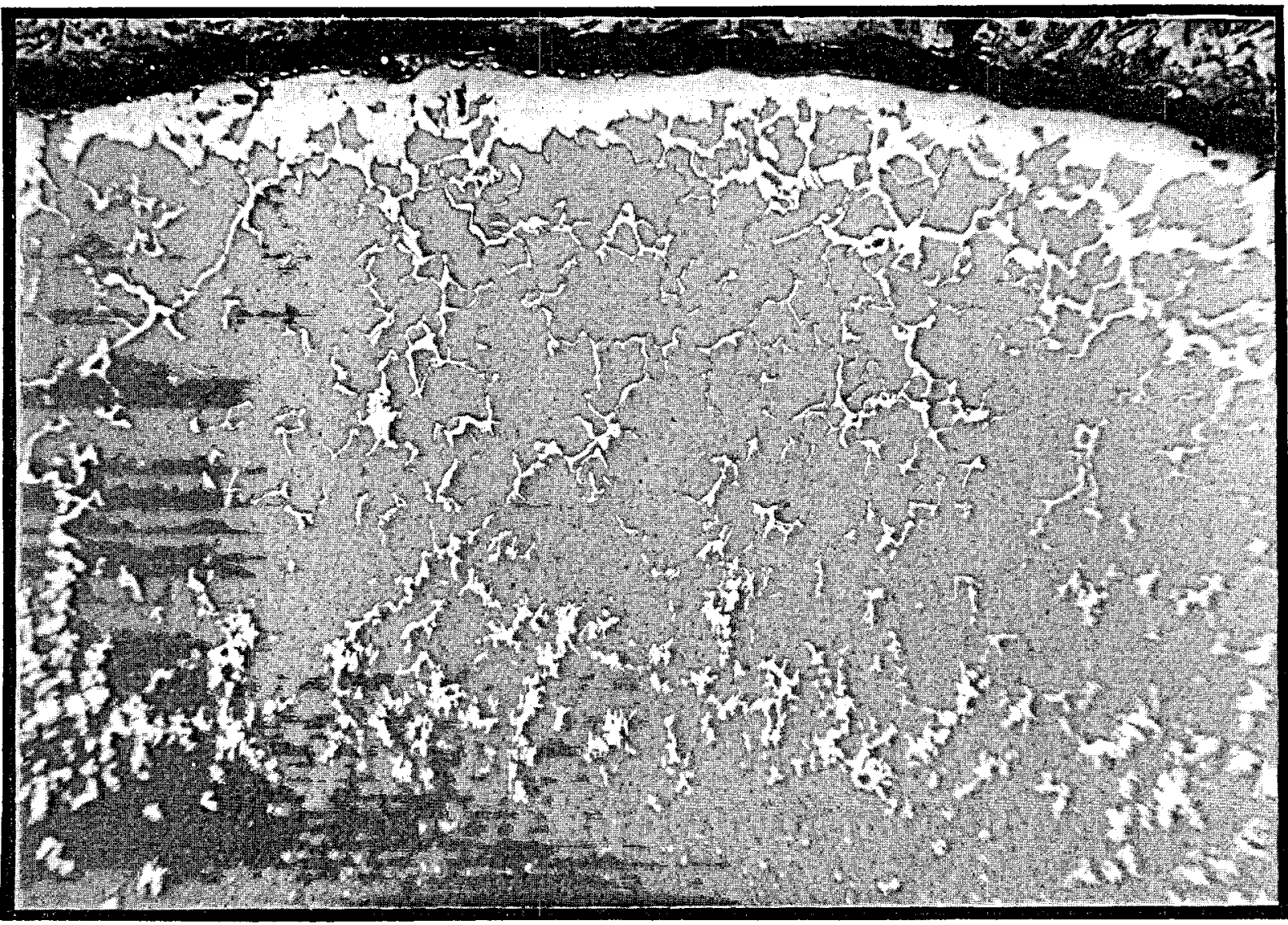

ETCHANT: ANODIZED

MAGNIFIED: $\quad 200 X$

EXTREME NITROGEN CONTAMINATION IS EVIDENCED BY $\mathrm{Cb}_{2} \mathrm{~N}$ (LIGHT). MINUTE DARK PARTICLES ARE $\mathrm{ZrO}_{2}$ PRECIPITATES. 
PW AC - 454

f16 20

$2920-10$

\section{Cb-1 Zr CLAD WALL ID REGION OF T/C FROM TEST WRI-2004}

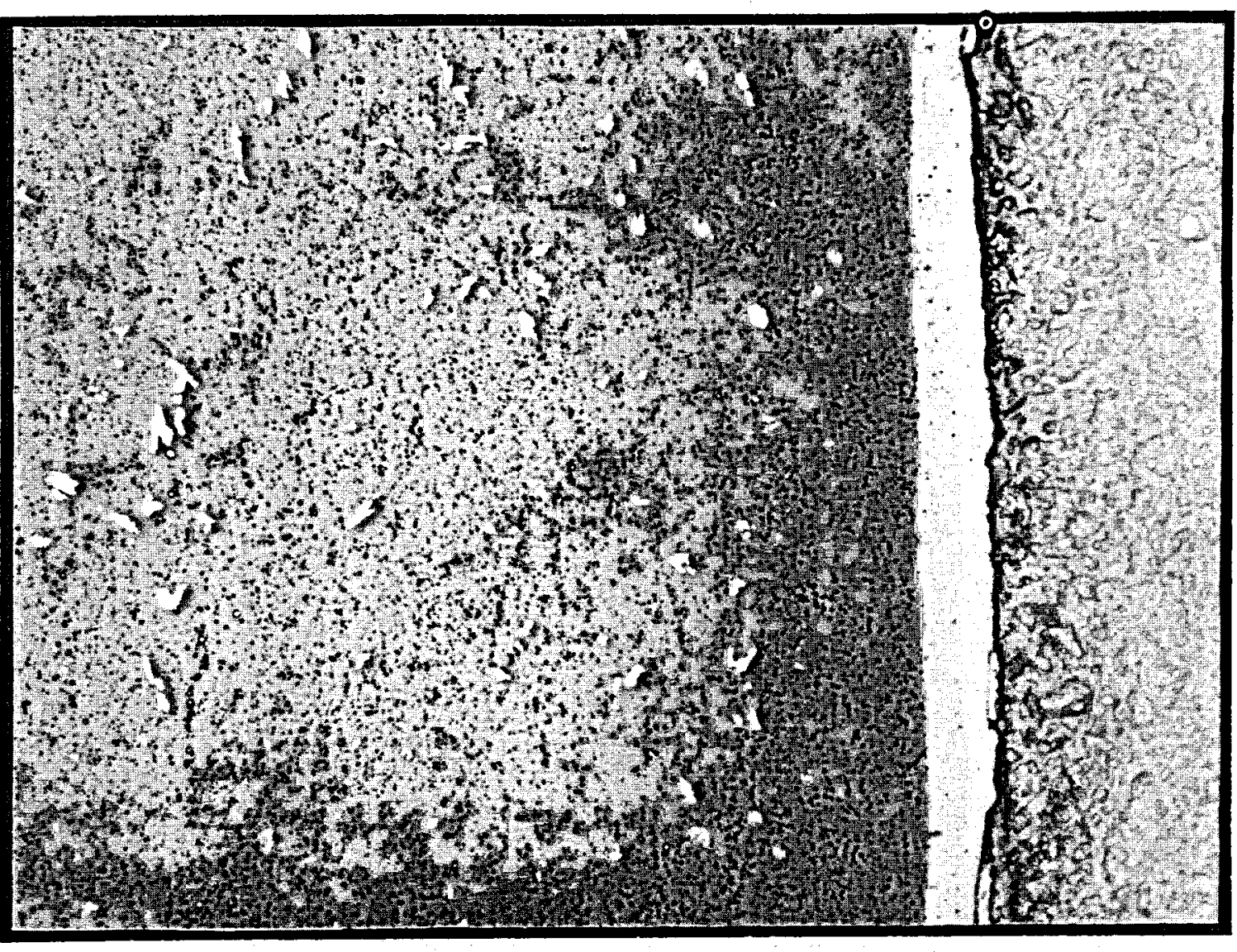

ETCHANT: ANODIZED

MAGNIFIED: $500 X$

LAYER FORMATIONS OF $\mathrm{Cb}$ A1 AND $\mathrm{Cb}_{3} \mathrm{~A} 1$ ARE SHOWN AT THE CLAD I.D. WHICH WAS ADJACENT TO THE ALUMINA. THE LIGHT PHASE DISTRIBUTED THROUGHOUT THE CLAD WALL IS $\mathrm{Cb}_{2} \mathrm{~N}$ AND THE MINUTE, DARK, SPHEROIDAL PHASE IS $\mathrm{ZrO}_{2}$. 


\section{Cb-1 Zr CLAD WALL ID REGION OF T/C FROM TEST WRI-2003}

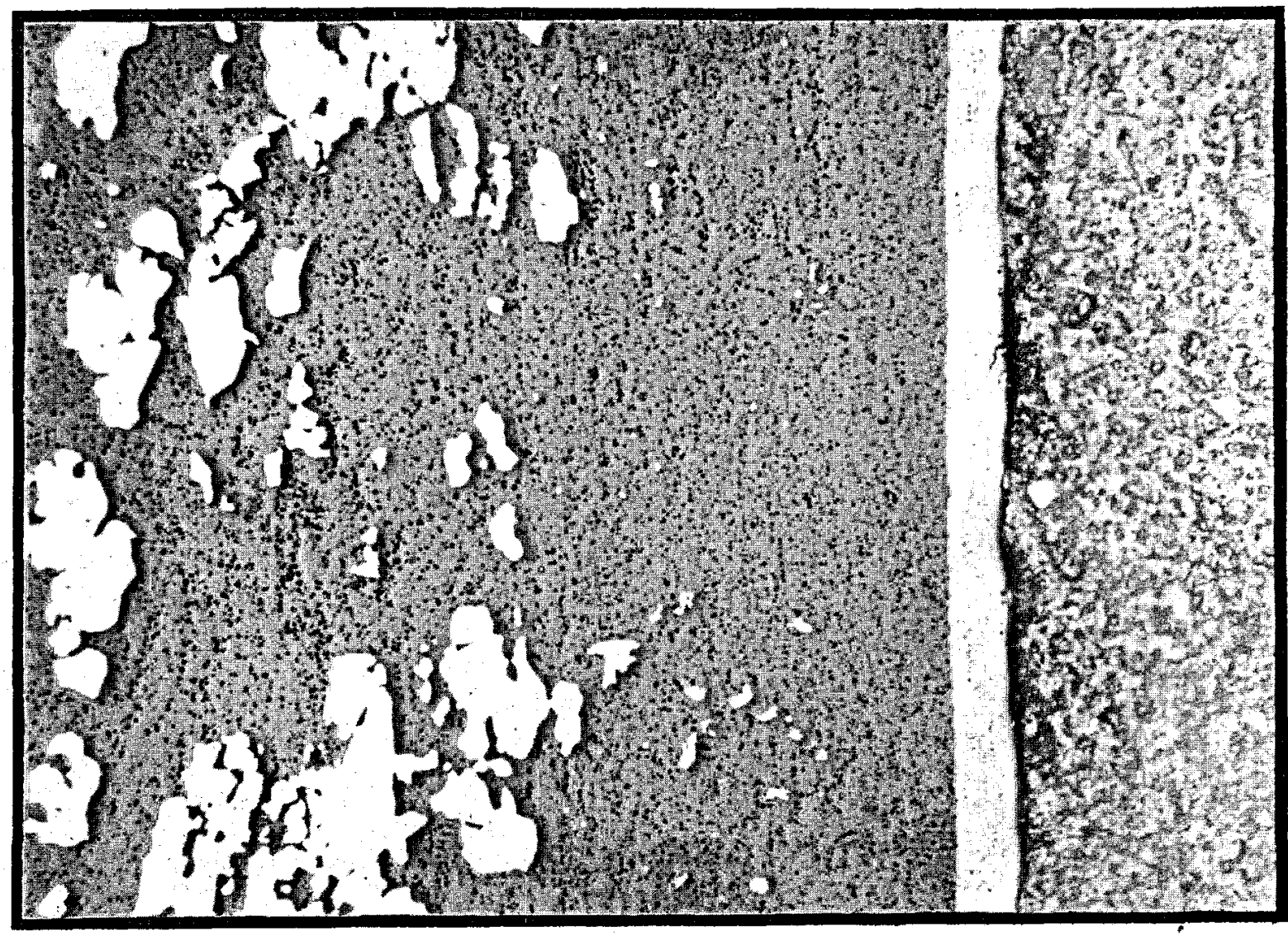

ETCHANT: ANODI ZED

MAGNIFIED: $500 X$

LAYER FORMATION OF $\mathrm{Cb}_{3} \mathrm{~A} 1$ IS NOTED ADJACENT TO THE ALUMINA. Cb ${ }_{2} \mathrm{~N}$ (LIGHT) AND $\mathrm{ZrO}_{2}$ (DARK) PHASES ARE SHOWN DISPERSED THROUGHOUT THE INTERIOR OF THE CLAD WALL. 
P WA C - 454

FIG 22

CONTAMINATION OF $\mathrm{Pt} / \mathrm{Pt}-13 \mathrm{Rh}$ BY MANGANESE

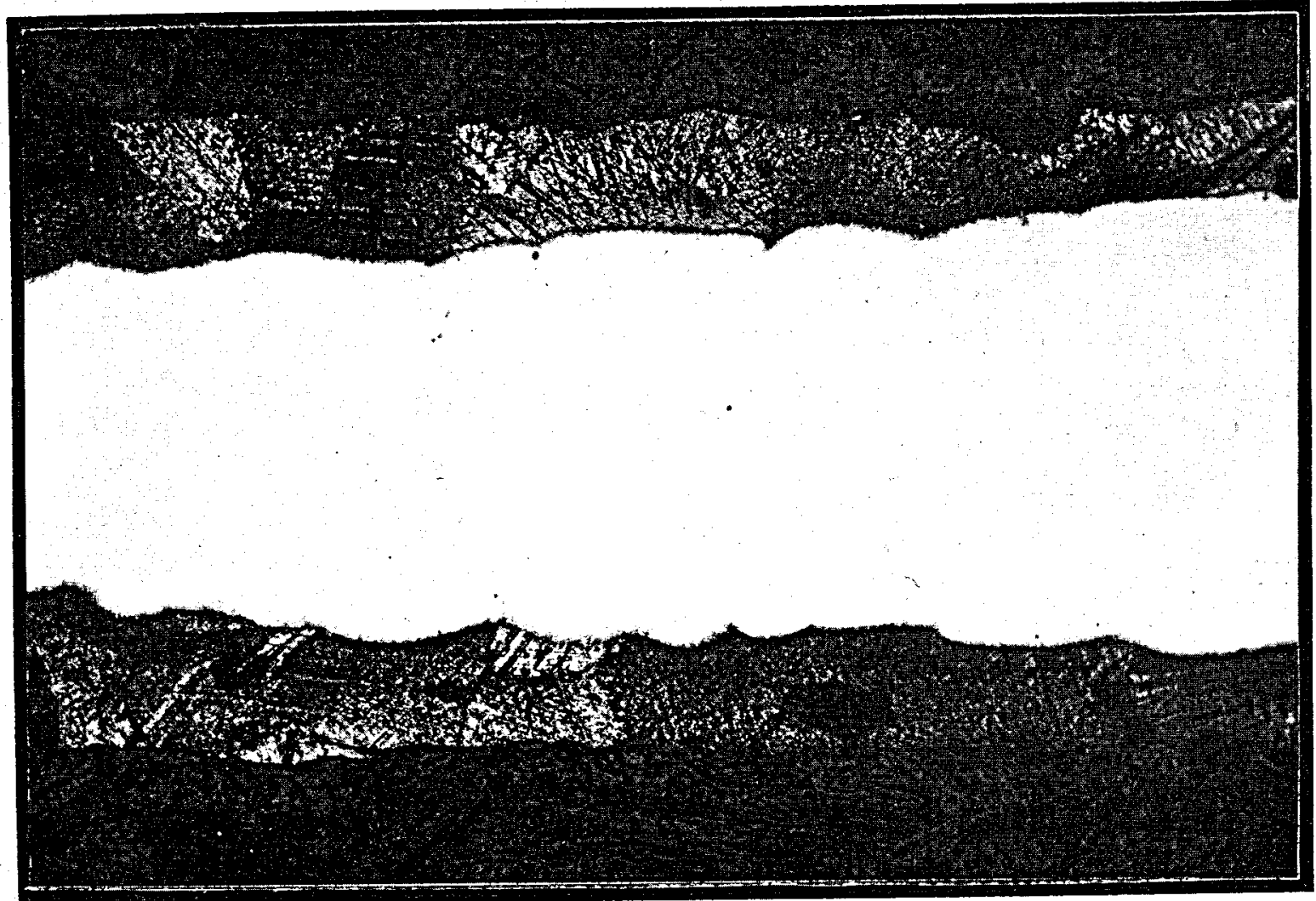

ETCHANT: AQUA REGIA

MAGNIFIED: $\quad 100 \mathrm{X}$

TYPICAL DIFFUSION PENETRATION (DARK) NOTED IN Pt/Pt-13 Rh T/C STANDARD USED IN TEST X531-B. ELECTRON MICROPROBE IDENTIFIED Mn AS THE ELEMENT WHICH DIFFUSED INTO THE WIRES. 


\section{CONCLUSIONS}

These tests have shown that thermocouples which are properly fabricated and protected can operate successfully at $2000 \mathrm{~F}$ for long periods. No failures occurred in any of the 43 thermocouples tested. The accuracy and drift data obtained was extremely good. One Chromel/Alumel test did exhibit a greater drift than anticipated. This cannot be explained except to say that enough tests have not yet been performed to statistically predict what the drift will be. No final numerical limit can be based on the performance described in this report because of this. What we have done is to obtain a high degree of confidence in the use of these thermocouples and not expect that drastic changes will occur in their thermoelectric output. As our program continues and more tests are operated, numerical statistical limits will be derived. 